NBER WORKING PAPER SERIES

\title{
WHY ARE POWER COUPLES INCREASINGLY CONCENTRATED IN LARGE METROPOLITAN AREAS?
}

\author{
Janice Compton \\ Robert A. Pollak \\ Working Paper 10918 \\ http://www.nber.org/papers/w10918
NATIONAL BUREAU OF ECONOMIC RESEARCH
1050 Massachusetts Avenue
Cambridge, MA 02138
November 2004

\begin{abstract}
We would like to thank Emek Basker, Scott Drewianka, Courtney Lafountain and participants at the Midwest Economics Association Meetings, the Canadian Economic Association Meetings and the Population Association of America Meetings for their helpful comments and suggestions. Pollak thanks the John D. and Catherine T. MacArthur Foundation for their support. The usual disclaimer applies. The views expressed herein are those of the authors and do not necessarily reflect the views of the National Bureau of Economic Research.

(C) 2004 by Janice Compton and Robert A. Pollak. All rights reserved. Short sections of text, not to exceed two paragraphs, may be quoted without explicit permission provided that full credit, including $\odot$ notice, is given to the source.
\end{abstract}


Why Are Power Couples Increasingly Concentrated in Large Metropolitan Areas?

Janice Compton and Robert A. Pollak

NBER Working Paper No. 10918

November 2004, Revised July 2006

JEL No. J61

\section{ABSTRACT}

Using census data, Costa and Kahn (QJE, 2000) find that power couples - couples in which both spouses have college degrees - are increasingly likely to be located in the largest metropolitan areas. One explanation for this trend is that college educated couples are more likely to face a co-location problem - the desire to satisfy the career aspirations of both spouses - and therefore are more attracted to large labor markets than are other couples. An alternative explanation is that all college educated individuals, married and unmarried, are attracted to the amenities and high returns to education found in large cities and that as a result, the formation of power couples through marriage of educated singles and additional education is more likely to occur in larger than smaller metropolitan areas. Using the Panel Study of Income Dynamics (PSID), we analyze the dynamic patterns of migration, marriage, divorce and education in relation to city size and find that power couples are not more likely to migrate to the largest cities than part-power couples or power singles. Instead, the location trends are better explained by the higher rate of power couple formation in larger metropolitan areas. Regression analysis suggests that it is only the education of the husband and not the joint education profile of the couple that affects the propensity to migrate to large metropolitan areas.

Janice Compton

Department of Economics, Campus Box 1208

Washington University in St. Louis

205 Eliot Hall

One Brookings Drive

St. Louis, MO 63130

jcompton@wueconc.wustl.edu
Robert A. Pollak

Department of Economics, Campus Box 1208

Washington University in St. Louis

205 Eliot Hall

One Brookings Drive

St. Louis, MO 63130

and NBER

pollak@wustl.edu 


\section{Introduction}

Couples in which both husband and wife have college degrees are increasingly likely to be located in large metropolitan areas. In 1970, 39\% of these couples - called "power couples" by Costa and Kahn (2000) - lived in metropolitan areas of at least two million. In 1990, this number had jumped to 50\%. By comparison, among couples in which only one spouse has a college education - "part-power couples" - the proportion living in large metropolitan areas increased more slowly, growing from $36 \%$ to $42 \%$ over the two decades. Couples in which neither spouse has a college degree - "low-power couples" - have the lowest probability of living in a large city and the lowest rate of increase, growing from $30 \%$ to $34 \%$ in twenty years. (Costa and Kahn, 2000)

Costa and Kahn consider two main explanations for the increasing concentration of power couples in large metropolitan statistical areas (MSAs). First, large metropolitan areas may be increasingly attractive to the college educated, regardless of their marital status. The increase in urbanization of the college educated may reflect higher returns to education in larger MSAs or urban amenities more commonly found there. Thus, the observed trends may be the result of college educated singles moving to large urban areas and then marrying. Second, the labor markets found in large metropolitan areas may hold particular attraction for power couples. All married couples potentially face the possibility that their location preferences will differ. This 'co-location problem' may arise from different preferences for amenities or proximity to family, but economists emphasize job opportunities. If husband and wife work in the paid labor market and if they live together, then they must both find acceptable employment in the same location. With the rise in married women's labor force participation, the potential for co-location conflict has increased for all couples, but may be most acute for the college educated because they tend to have more specialized careers. Solving this type of co-location problem may be easier in the labor markets of large metropolitan areas, and thus these areas should be magnets for power couples.

Costa and Kahn conclude that the ability of large MSAs to solve the co-location problem explains most of the observed increase in the concentration of power couples in large MSAs. Although the data used in 
their analysis are cross-sectional, they suggest that the migration of power couples is the principal mechanism underlying the changes in observed location patterns.

In this paper we investigate the relationship between migration and the education profiles of couples. We ask two questions. First, is there evidence that the co-location pressure faced by highly educated couples is a determinant of migration? That is, compared to other couples, are power couples more likely to migrate into, and less likely to leave, large MSAs? Second, do the migration patterns of power couples differ from those of other couples? Positive responses to these questions would support Costa and Kahn's co-location explanation for the concentration of power couples in large urban areas. We do not, however, find evidence supporting the co-location explanation.

Using data from the Panel Study of Income Dynamics (PSID), we find that, holding all else equal, power couples are more likely to migrate and, when they migrate, are more likely to migrate to large urban areas than low-power couples. We find, however, that the factor determining couples' migration is not their joint education profile but the husband's education. More specifically, we find that the migration behavior of part-power couples in which only the husband is a college graduate is indistinguishable from that of power couples, while the migration behavior of part-power couples in which only the wife is a college graduate is indistinguishable from that of low-power couples. Our conclusion that migration is affected by the husband's education rather than the couple's joint education profile is unaltered when we include controls for post-graduate education and occupation to identify those couples most likely to have specialized careers.

Logic suggests that the observed location of power couples must be the resultant of four dynamic processes: migration, marriage, divorce, and human capital accumulation. Looking at the stock of power couples living in large metropolitan areas, we can conclude only that each spouse must have earned a college degree, married a spouse who earns/earned a college degree, remained married, and migrated to and/or chosen to remain in a large metropolitan area.

We argue that the migration of power couples into large urban areas is unlikely to be the primary mechanism behind the concentration of power couples in large MSAs. The formation of power couples in large MSAs provides a more plausible explanation. Although the differences between groups are not 
precisely estimated, the patterns suggest that differences in the migration rates of power singles, in assortative mating patterns, and in college enrollment rates by city size may be responsible for the increasing concentration of power couples in large MSAs. This suggestion is strengthened by the 2000 census data, data unavailable to Costa and Kahn. Between 1990 and 2000 the proportion of power couples living in large MSAs fell, while the proportion of low-power couples in large MSAs increased. This reversal of the earlier trend is difficult to explain in terms of power couple migration and co-location pressure.

The paper proceeds as follows. Section 2 provides a brief review of the literature on couple migration. In section 3 we describe the data, the econometric model, and the variables we use to investigate the relationship between the joint education profile of spouses and the probability of migration. Regression results are presented in section 4 . Section 5 provides an overview of couple migration patterns as well as the other mechanisms that may explain the location trends - migration of singles, assortative mating, marriage and divorce trends, and educational attainment by city size. Section 6 reports on changes in power couple concentration in large urban areas using data from the 2000 census. Section 7 concludes.

\section{Migration of Couples}

Economists frame individuals' migration behavior as human capital decisions (Mincer, 1978: Sjaastad 1962). A person will migrate if the expected benefit of living in another location less migration costs exceeds the expected benefit of remaining in the current location. The main statistical trends of migration are consistent with this model - younger individuals are more mobile than older individuals, more educated persons are more mobile than those with less education, rural to urban migration is more common than the reverse, and the longer individuals have resided in an area the less likely they are to migrate. (For a review of the migration literature, see Greenwood, 1997).

Polachek and Horvath (1977), Sandell (1977) and Mincer (1978) were among the first to frame the migration decision explicitly in terms of family net gain rather than individual net gain. These researchers abstract from decision making within the family and assume that families migrate if and only if the sum of the benefits of migrating is greater than the sum of the costs, where the sums are taken over all family 
members. Family migration is less likely than individual migration since the costs of migrating increase with the number of family members while the benefits may not. The model suggests that one spouse, typically the husband, is often a 'tied-stayer' while the wife is often a 'tied-mover'. Tied-stayers forgo moves that would result in positive net returns for the individual, but negative net returns for the family. Tied-movers participate in moves that result in a loss for themselves but positive net returns for the family.

Empirical work confirms the importance of husbands' career opportunities in migration decisions. Using a sample of college graduates, Duncan and Perrucci (1976) show that the higher the occupational prestige and migration opportunities connected to the husband's occupation, the greater the probability that the couple will migrate. They find, however, that the occupational prestige and migration opportunities of the wife's career did not affect migration probabilities. Using data also from the 1970s, Bielby and Bielby (1992) link the migration behavior of couples to gender-role beliefs. Couples who subscribe to a more traditional "provider role" for husbands will not be deterred from moves that harm the wife's employment opportunities but will be deterred from moves that harm the husband's career opportunities. More recent studies continue to find similar gendered determinants of couple migration (Gardner et al. 2001; Nivalainen 2004).

Unlike these large-scale statistical studies, Green (1997) uses a case-study approach to investigate the migration/location decisions of dual-career households. On the basis of interviews with thirty such couples, she finds that the leader in migration decisions is most often the spouse with (a) the more highly paid career; (b) the more locationally constrained career; and/or (c) the more insecure career. In the large majority of cases, the spouse with these job characteristics was the husband. Green notes that although the respondents appreciate the greater career opportunities in large urban centers, many are unwilling to incur the costs associated with such large areas - high costs of living, congestion, etc. (Green, 1997).

Because career choice is endogenous to beliefs about migration and marriage, Frank (1978) argues that expectations of migration based on the maximization of net family welfare help explain the male-female wage gap. Women are less likely to invest in their own human capital when their opportunity set is limited by their husbands' locational choices. Similarly, if employers believe that the location decisions of women 
are determined largely by their husbands' careers and not their own, employers may be less likely to invest in firm-specific human capital for women. As a result, women may tend to enter more mobile careers - careers that build largely on general, rather than specific human capital and careers in which opportunities are not concentrated in large urban areas. Studies of couple migration by Shihadeh (1991), Morrison and Lichter (1988), Spitze (1984), Bird and Bird (1985), Cooke and Bailey (1996), and Jacobsen and Levin (1997) are broadly consistent with Frank's argument.

Robst and McGoldrick (1996) investigate the impact of destination size on outcomes for tied movers. They began by hypothesizing that while a trailing spouse has a job search limited to the location that the leading spouse has chosen, if the location is a large MSA and this in turn reflects higher job vacancies, then the trailing spouse may find a wage offer near the maximum that could be obtained in a nationwide search. This hypothesis was not supported by the data. The authors found that the size of the local labor market had no significant effect on the likelihood of women being "overeducated", i.e., having a higher level of education than the average within their occupation. They suggested that it is not the market's size that is important, but its job composition: a small local labor market with a relatively large concentration of whitecollar employment is as beneficial to women as a large labor market without such a concentration.

\section{Econometric Model and Data Description}

Our econometric analysis addresses the following question: compared to part-power and low-power couples, are power couples more likely to migrate to and less likely to migrate from large cities? To answer this question, we consider the determinants of couple migration, focusing on couples' joint education profiles.

\subsection{Data}

The regression analyses presented in the following sections use data from the Panel Study of Income Dynamics (PSID). The PSID is a longitudinal survey of a representative sample of American individuals and 
families. The original sample included members of 4800 families. All individuals from the original families are followed as they move or form new family units. For this study we have included all married couples who live together and all unmarried heterosexual couples who have lived together for at least one year. ${ }^{1}$ In all that follows, we define 'power couples' as those in which both husband and wife have a bachelor's degree; 'part-power couples' as those in which only one spouse holds a bachelor's degree; and 'low-power couples' as those in which neither spouse holds a bachelor's degree. ${ }^{2}$ When we refer to an individual as "college educated" we mean that he or she holds a bachelor's degree. The sample is limited to men aged 2539 and women aged 23-37. This restriction allows us to focus on those individuals and couples whose migration decisions would be most influenced by career considerations. ${ }^{3}$

The Geocode Match Supplement to the PSID provides detailed geographic identifiers necessary for a migration study. Building up from the county of residence, we sort observations into Metropolitan Statistical Areas (MSAs). The U.S. Census Bureau defines MSAs as agglomerations of counties that include a large population nucleus and adjacent communities that share a high degree of social and economic integration. We define migration as a move between MSAs, between an MSA and a non-MSA county, or between two non-MSA counties. Thus, moves within an MSA are not treated as migration. The changing definition of MSAs poses a problem for migration analysis. For example, according to the 1990 MSA definitions, Baltimore MD and Washington DC were distinct MSAs, but according to the 2000 definitions they are part of a single MSA. To prevent changing MSA definitions from creating the appearance of changes in

\footnotetext{
${ }^{1}$ Dropping couples who were not legally married did not alter the results in preliminary analyses.

${ }^{2}$ Some imputation was required for the education variable. Education was asked of respondents when they entered the household but not at each subsequent round. In 1985, the education questions were re-asked of all individuals in the sample. Since year of graduation was asked, it was possible to work backwards from 1985 to code the education attainment for previous years. For years after 1985, only new heads/spouses were asked the education questions. For those already in the sample, if they were enrolled in school in 1985, they were assumed to have finished their program and so a degree was imputed to them in following years. If individuals were not enrolled in school in 1985, their education level observed in 1985 was simply carried forward. The resulting imputations look reasonable in comparison to average education of the individual's occupation. A robustness test was performed in which education was raised to be at least the minimum level of education that individuals who reported the same occupation deemed necessary to perform the job. The results are not substantially different.

${ }^{3}$ These age categories are the focus of Costa and Kahn (2000). Similar trends in location are found with expanded age categories.
} 
migration rates, we apply the 1990 MSA definitions consistently throughout the sample. ${ }^{4}$ In the analyses that follow, we define "large" metropolitan areas as MSAs with populations greater than two million, "midsize" metropolitan areas as MSAs with populations between 250,000 and two million, and "small" metropolitan areas as non-metropolitan areas and MSAs with populations less than 250,000. We choose these categories to be consistent with those used by Costa and Kahn. Appendix A lists the large MSAs for the 1970-2000 period.

In our regression analyses we use data for the period 1980-1993. We limit our analysis to these years because some of the relevant variables-most importantly, the education variables-were not available for any longer period. Since it is during this period that we observe the greatest increase in power couple concentration in large MSAs, we would expect the co-location effect to be strongest during this period. The panel data are pooled into twelve two-year cross-sections. For each couple-year observation, the dependent variable captures the migration behavior observed in year two and all independent variables measured in year one. Our sample includes 21955 couple-year observations with 638 observed migrations (3\%).

\subsection{Econometric Model}

We estimate two econometric models of migration. In the first we estimate the probability of migrating without regard to the destination. The dependent variable is binary, indicating whether or not the couple migrates. In the second model we distinguish migrants by the size of destination. Here, the couple chooses among four alternatives: staying in the current location, migrating to a small MSA, migrating to a midsize MSA, and migrating to a large MSA. The decision to migrate and the size of destination are determined simultaneously.

\footnotetext{
${ }^{4}$ Costa and Kahn, whose focus is not dynamic, use the current year MSA definition for each census year that they consider but they note that their results do not change substantially under alternative (stable) definitions.
} 


\subsubsection{Sample Selection Issues}

Two selection issues require attention. The first is attrition: the requirement that migration variables be defined in year two results in the loss of observations. The second is change in marital status: because our observations are at the household level - unmarried individual heads of households and married couples and are defined over a two-year period, the marital status must be constant over the two years. Hence, the location in year two is defined only for those couples that remain married. As a result, our samples are doubly selected to include only those observations that (i) have not been lost to attrition and (ii) have the same marital status in year two as in year one. Beginning with a sample of 26324 couple-year observations, we lose 2264 observations to attrition and 1354 observations to divorce. We dropped 751 additional observations due to missing values for key variables or death.

The model for the binary choice decision is a three-equation latent dependent variable model where equation (1) estimates the probability of remaining in the sample in year two (i.e., no attrition), equation (2) estimates the probability of remaining married in year two, and equation (3) is the equation of interest, estimating the probability of migration

$$
\begin{array}{ll}
q_{i}^{*}=V_{i} \delta+v_{i} & i=1 \ldots N_{1} \\
z_{i}^{*}=W_{i} \gamma+\omega_{i} & i=1 \ldots . N_{2}, N_{2}<N_{1} \\
y_{i}^{*}=X_{i} \beta+u_{i} & i=1 \ldots . . N_{3}, N_{3}<N_{2}
\end{array}
$$

where $q_{i}^{*}, z_{i}^{*}$ and $y_{i}^{*}$ are unobserved latent variables; $V_{i}, W_{i}$ and $X_{i}$ are $K, J$ and $M$ row vectors of exogenous explanatory variables; and $\delta, \gamma$ and $\beta$ are $K, J$ and $M$ column vectors of parameters to be estimated. The full sample is denoted $\mathrm{N}_{1} ; \mathrm{N}_{2}$ includes all couples who are present in both years; and $\mathrm{N}_{3}$ includes all couples who remain married in year two. We assume all three disturbance terms are drawn from normal distributions. In the absence of selection bias, we assume $v_{i}, \omega_{i}$ and $u_{i}$ are identically and independently normally distributed zero mean error terms.

Following Vella $(1998,1992,1993)$ and Eklof and Karlsson (1999) we test for sample selection in the binary choice model. Rewrite equation (1) as: 


$$
y_{i}^{*}=X_{i} \beta+\lambda_{1} \omega_{i}+\lambda_{2} v_{i}+\eta_{i} \quad i=1 \ldots N_{1}
$$

where $\lambda_{1}$ and $\lambda_{2}$ are equal to $\sigma_{u \omega} / \sigma_{u}^{2}$ and $\sigma_{u v} / \sigma_{u}^{2}$ respectively. The term $\eta_{i}$ is a white noise error term. Replacing $\omega_{i}$ and $v_{i}$ with the estimated generalized residuals from the probit models - which by Vella (1993) are equal to their respective inverse Mills ratios, we estimate

$$
y_{i}^{*}=X_{i} \beta+\lambda_{1}\left[\frac{\phi\left(z_{i}^{\prime} \gamma\right)}{\Phi\left(z_{i}^{\prime} \gamma\right)}\right]+\lambda_{2}\left[\frac{\phi\left(q_{i}^{\prime} \delta\right)}{\Phi\left(q_{i}^{\prime} \delta\right)}\right]+\eta_{i} \quad i=1 \ldots N_{1} .
$$

Under the null hypothesis, $\lambda_{1}$ and $\lambda_{2}$ are equal to zero and $\eta_{i}$ is equal to $u_{1}$. The t-tests on $\lambda_{1}$ and $\lambda_{2}$ are tests of selection bias since under the null hypothesis the estimates are consistent. In general, however, under the alternative hypothesis, the estimates are not consistent.

The test results are presented in table 1 . Shown are some key variables as well as the test statistics. ${ }^{5}$ Column A presents the binary choice probit regression (equation (1)) without adjusting for sample selection. Column B presents the results from equation (5), including the two test statistics. As indicated by the t-tests, neither $\lambda_{1}$ nor $\lambda_{2}$ are significant. In the regressions presented in columns $\mathrm{C}$ and $\mathrm{D}$ we alter the modeling of sample selection. In column $\mathrm{C}$ the two selection criteria are combined. In this model the first step equation estimates the probability of being observed in year two (i.e., no divorce and no attrition). In column $\mathrm{D}$ the observations that have been lost due to attrition are simply dropped and we model only the sample selection arising from divorce. ${ }^{6}$ In both variations, the t-test indicates insignificant test variables.

${ }_{6}^{5}$ Full regression results for table 1 are presented in appendices $\mathrm{C}(\mathrm{i})$ and $\mathrm{C}(\mathrm{ii})$.

${ }^{6}$ More formally, in column $\mathrm{C}$ we present a variation of equation (5):

$$
\begin{aligned}
& y_{i}^{*}=X_{i} \beta+\lambda_{3}\left[\frac{\phi\left(z_{i}^{\prime} \gamma\right)}{\Phi\left(z_{i}^{\prime} \gamma\right)}\right]+\eta_{i}, \quad i=1, \ldots . N_{1}, \\
& z_{i}^{*}=W_{i} \gamma+\omega_{i}, \quad i=1, \ldots . N_{1}
\end{aligned}
$$

where $z_{i}^{*}$ estimates the probability that individual i is observed and married in year two. Likewise, in column D we presents the following variation of equation 5 :

$$
\begin{aligned}
& y_{i}^{*}=X_{i} \beta+\lambda_{1}\left[\frac{\phi\left(z_{i}^{\prime} \gamma\right)}{\Phi\left(z_{i}^{\prime} \gamma\right)}\right]+\eta_{i}, \quad i=1, \ldots . N_{2}, \\
& z_{i}^{*}=W_{i} \gamma+\omega_{i}, \quad i=1, \ldots . N_{2}
\end{aligned}
$$


Column E estimates the abridged model of column D under a maximum likelihood probit estimation procedure outlined by van de Ven and van Praag (1981) and implemented through STATA using the HECKPROB command. ${ }^{7}$ The estimates in this model are consistent and asymptotically efficient even in the presence of selection bias as it allows for the estimation of the correlation between the error terms $\omega_{i}$ and $u_{i}$. The likelihood ratio test of independent equations - testing the null hypothesis that $\rho=0$ - indicates again that sample selection bias is not a concern.

Overall, the t-tests on the inverse Mills ratios added to the regressions in columns B through D and the likelihood ratio test in column E indicate that sample selection bias is not significant in this model. In the analyses that follow, we present the binary choice estimation results from the maximum likelihood probit model.

For the second model, in which size of the destination is determined jointly with the decision to migrate, we rely on the above test results and estimate the model under the assumption that sample selection bias is not significant. Here we employ a multinomial logistic specification and estimate the following model using a maximum likelihood procedure. ${ }^{8} \quad$ Extending the binary model from (4), the probability that observation $i$ chooses outcome $j$ is:

$$
p_{j i}=\operatorname{Pr}\left(Y_{i}=j\right)= \begin{cases}\frac{1}{1+\sum_{m=2}^{4} \exp \left(X_{i} \beta_{m}\right)}, & \text { if } j=1 \\ \frac{\exp \left(X_{i} \beta_{j}\right)}{1+\sum_{m=2}^{4} \exp \left(X_{i} \beta_{m}\right)}, & \text { if } j=2,3,4\end{cases}
$$

where observations lost to attrition are dropped from the sample and $z_{i}^{*}$ estimates the probability that individual $i$ is married in year two.

${ }^{7}$ Maximum likelihood estimates in which the missing observations are dropped and selection is solely due to marital stability are similar.

${ }^{8}$ Although we assumed a normal distribution in the first case, we assume a logistic error distribution here. As we have no a priori beliefs concerning the distribution of the errors, the choice of error form was determined solely by ease of computation. While it would have been more consistent to estimate multinomial probit regressions, convergence was difficult. The binary choice regressions were run under the assumption of logistic errors and the results were very similar. 
Where $j=1,2,3,4$ denotes the four categorical outcomes (not migrating, migrating to a small MSA, migrating to a mid-size MSA, migrating to a large MSA); the base outcome $(j=1)$ is the choice of not migrating. In the results that follow, we present the relative risk ratios, which are equal to the exponentiated value of a coefficient. This allows for an easy interpretation: the relative risk ratio indicates the change in the probability of observing outcome $\mathrm{k}$, relative to the probability of not migrating, for a one unit change in the corresponding variable.

\subsubsection{Endogeneity}

Migration and education are endogenous if individuals have unobservable characteristics that are reflected in a higher propensity to invest in human capital through both education and migration. To correct for unobserved heterogeneity in the propensity to invest in human capital, we control for whether the current state is the home state of either spouse and whether or not the household head (read: husband) has previously moved in order to take a job. The inclusion of these variables weakens the endogeneity concerns as they capture some of the otherwise unobservable propensity to invest in human capital. Indeed with the inclusion of these variables, Hausman tests allow us to reject the null hypothesis of endogeneity at the $5 \%$ confidence level. Column $\mathrm{F}$ in table 1 highlights the importance of these variables. While the results are robust to inclusions and omissions of other control variables, the omission of these variables significantly alters the impact of the education variables.

\subsubsection{Control Variables}

In the following discussion, we focus on couples' joint education profile as a determinant of migration, controlling for other factors such as family, location amenities, employment, and occupation. Appendix B shows means and standard deviations for the full sample, which includes all couple-year observations, and separately for the migrant observations. The means show the strong importance of the couples' home state and previous migration behavior. Close to $80 \%$ of the couple observations are residing in the home state of at least one spouse. Compare this with only $45 \%$ of migrant observations. In $26 \%$ of all 
observations, the head had moved previously for a job; the corresponding figure for migrant observations is $38 \%$. In our sample, migrants are younger, slightly less likely to have pre-school children, less likely to be home owners, and less likely to be non-white. Migrants' origins tend to be characterized by slower growth, higher housing value, and greater distance to any large MSAs. In terms of labor force attachment, migrants have lower job durations and are more likely to be unemployed or out of the labor force.

\section{Regression Results}

The regression analysis provides no evidence that co-location pressure is a determinant of migration. Tables 2-5 provide key regression results. ${ }^{9}$ For the binary model, the marginal effects of the key variables are presented - the change in the probability of migrating due to a change in the dummy variable from zero to one. For the multinomial model, the results are presented as relative risk ratios. For a dummy variable, this is the change in the probability of migrating to the indicated destination size over the probability of not migrating that occurs due to a discrete change in the variable from 0 to 1 .

\subsection{The Effect of Power Couple Status on Migration}

Table 2 presents the results for key variables in the binary model. Column A corresponds to column E in table 1 and controls for sample selection using maximum likelihood estimation. The regression results show that it is not the joint education profile of a couple but only the husband's education that affects the decision to migrate.

The analysis hinges on the behavior of couples in which one spouse has a college degree and the other does not (i.e., the part-power couples). In column A, we pool the part-power couples in which the husband is a college graduate with the part-power couples in which the wife is a college graduate. Point estimates indicate that power couples are more likely to migrate than both part-power couples and low-power couples, although the Wald test shows that the difference between the coefficients on power couples and

\footnotetext{
${ }^{9}$ Full regression results are provided in appendix D for the preferred specifications - the regressions presented in column B, table 2 and column B, table $3 \mathrm{a}$. Other regression results are similar.
} 
part-power couples is not statistically significant at a 95\% confidence level. Holding all else constant, the probability of migration for a power couple is $2.2 \%$ higher than the probability of migration for a low-power couple. In column B, we split the part-power couples into those in which the husband is a college graduate and those in which the wife is a college graduate. We find that the migration propensity of power couples is indistinguishable from that of part-power couples in which the husband has a college degree, and that the migration propensity of low-power couples is indistinguishable from that of part-power couples in which the wife has a college degree. When we ignore joint education specifications and control for the husband's education, we find no statistically significant effect of the wife's education on the probability of migration (column C). Wald tests on the coefficients confirm that the effects of husband's and wife's education on the propensity to migrate are statistically different. These results suggest that it is not the joint education profile of a couple that affects migration, but only the husband's education. Finally, in column D we find that while the probability of migrating is lower for couples living in large MSAs compared to couples living in small MSAs, the interaction variables show that there is no differential impact of origin size by education.

The coefficients on other variables are as expected. The variables included to capture past behavior - whether or not the couple is residing in the home state of at least one spouse, and whether or not the head has previously moved for a job - remain constant in size and significance across model specifications. Living in the home state of at least one spouse reduces the probability of migrating by $2.2 \%$, while prior migrants are $0.4 \%$ more likely to migrate compared to couples in which the head has never previously moved for a job.

As noted above, these binary regressions are run simultaneously with a sample selection equation. The statistical significance of the variable $\rho$ provides a test of sample selection bias. In all but column $\mathrm{D}$, we can accept the null hypothesis that $\rho=0$, that is, that the two equations are independent and controlling for sample selection is not providing any further information.

Tables $3 \mathrm{a}$ and $3 \mathrm{~b}$ present the results from the multinomial logit regressions, which confirm the crucial role of husband's education in migration, especially migration to large MSAs. These regressions do 
not control for sample selection because sample selection bias was significant in only one of the binary regressions. For columns A through $\mathrm{C}$ then, this omission is unimportant.

The first regression, presented in column A, again does not distinguish between the two groups of part-power couples. The propensity to migrate to large MSAs is higher for both power and part-power couples, compared to low-power couples. The results for these regressions are presented as relative risk ratios, indicating that power couples are 2.8 times more likely to migrate to a large MSA compared to lowpower couples, while part-power couples are 3.4 times more likely. Column B distinguishes between partpower couples in which the husband holds a college degree and part-power couples in which the wife holds a college degree. As in the binary regressions, this distinction is important. Compared to low-power couples, both power couples and part-power couples in which the husband has a college degree are more likely to migrate to medium MSAs and to large MSAs. Part-power couples in which the wife holds a college degree are indistinguishable from low-power couples in their propensity to migrate to cities of all sizes. Column C considers only the education of each spouse, and not their joint profile. Again we find that couples in which the husband holds a college degree are more likely to migrate to a large MSA. The estimated effect of a wife's college education on the probability of migrating to a large MSA is negative, although the precision of this estimate is low.

In all three regressions presented in columns A-C, couples living in large MSAs are less likely to migrate to small MSAs. Couples living in midsize MSAs are more likely to migrate to large MSAs (with slightly lower levels of significance). These trends indicate a general reluctance to move to a smaller metropolitan area and a general preference for moving to a larger MSA. The regression results presented in column D indicate that the education category of the couple has some impact on this preference for larger MSAs. Couples in which only the wife has a college degree are less likely to migrate from one large MSA to another large MSA, and more likely to migrate from a large MSA to a midsize MSA, compared to lowpower couples. However, the results for column D are questionable. Not only is sample selection bias an issue in this specification, but we also find a violation of the assumption of independence of irrelevant 
alternatives. Hausman test results suggest that the omission of the small or medium alternatives alters the results for the large alternative.

We see again the robust significance of the past behavior variables. Residing in the home state of at least one spouse lowers the probability of migration to any sized destination. Interestingly, having previously moved for a job has no discernable effect on the probability of migrating to a medium or large MSA, but increases the probability of migrating to a small MSA. This suggests that we may be capturing return migrants.

Both the binary probit regressions and the multinomial logit regressions show that the probability of migration, and the migration to destinations of different sizes, depends not on the number of spouses holding a college degree (low-power, part-power, and power) but only on whether the husband holds a college degree.

\subsection{The Effect of Post-Graduate Degrees and Urban Occupations on Migration}

To link the co-location hypothesis to the education profile of couples we must assume that, for couples with college degrees, occupational specialization makes co-location pressure more acute. But many college educated individuals, women especially, are in occupations that are relatively portable and are not concentrated in large urban areas - the occupational specialization story is more plausible for an economist married to a lawyer than for a high-school teacher married to a nurse. $50 \%$ of power couples and $55 \%$ of power singles lived in large urban areas in 1990. Economists and lawyers tend to have advanced degrees and are relatively concentrated in large areas $-59 \%$ of economists and 55\% of lawyers lived in large MSAs in 1990. In contrast, teachers and nurses are less likely to have advanced degrees and are not concentrated in large areas $-33 \%$ of teachers and 38\% of registered nurses live in large MSAs in 1990 (see appendix C). The migration behavior of couples in which both spouses have post-graduate degrees - call these 'super-power couples' - or both spouses have occupations that are concentrated in large MSAs might be very different from the behavior of power couples without advanced degrees or urban occupations. 
We apply the same regression analyses as above to investigate whether co-location effects can be found for couples in which both spouses have occupations that are concentrated in large MSAs or both spouses have advanced degrees (tables $4,5 \mathrm{a}$ and $5 \mathrm{~b}$ ). There are 1778 observations in which at least one spouse has an advanced degree. These include 257 observations in which both spouses have advanced degrees, 986 observations in which only the husband has an advanced degree, and 535 observations in which only the wife has an advanced degree. Likewise, there are 3493 observations in which at least one spouse has an urban occupation, including 1740 observations in which both spouses have urban occupations, 4716 in which only the husband has an urban occupation, and 1282 observations in which only the wife has an urban occupation. We first include a measure of the urbanization of occupations - the percent of all individuals in the occupation that reside in MSAs greater than 2 million. ${ }^{10}$ This variable is added as a continuous variable (column E) and as a dichotomous variable (column F) that defines urban occupations as those where at least $40 \%$ of individuals in the occupation live in large MSAs. This cutoff was chosen to correspond roughly to the proportion of all individuals living in large MSAs. In 1990, approximately $36 \%$ of all couples and $43 \%$ of singles lived in large urban areas. Urban occupations then are those that are more than proportionately located in large MSAs. ${ }^{11}$ We create categories to describe 'urban' and 'part-urban' couples by occupation in the same way we describe power and part-power couples by education - controlling for couples in which both spouses have urban occupations, where only the husband has an urban occupation and where only the wife has an urban occupation. In columns $\mathrm{G}$ and $\mathrm{H}$ we add indicators for post-graduate college degrees, again creating categories to describe the joint profile of the couple.

We find few significant effects of urban occupation or advanced education in either the binary or the multinomial equations. Those variables that are significant confirm the importance of the husband's career in migration. Couples in which only the husband is employed in an urban occupation are more likely to migrate than couples in which neither has an urban occupation (table 4, column F). The multinomial logit regression results (tables 5 and $5 \mathrm{~b}$ ) are difficult to interpret. Couples in which only the husband is employed

\footnotetext{
${ }^{10}$ Rates of occupation urbanization are calculated from the 1990 public use files of the Census (Ruggles and Sobeck, 1997). Results are shown in appendix E

${ }^{11}$ The regression results are robust to alternative percentages used to define urban occupations.
} 
in an urban occupation are more likely to migrate to a mid-size MSA compared to couples in which neither spouse is employed in an urban occupation, while couples in which only the husband has an advanced degree are more likely to migrate to small and large MSAs Thus even under a more stringent definition of who is most affected by occupation specialization we find no evidence that co-location pressure affects migration behavior. The coefficients for college education maintain statistical significance and have similar magnitude when we control for the concentration of occupations in large urban areas. The stability of the college education variables after controlling for occupation suggests that in addition to employment opportunities, amenities and/or returns to education are pulling college graduates to large MSAs. ${ }^{12}$

\section{The Four Processes Underlying the Location Data}

The regression results presented above suggest that the co-location problem facing power couples does not manifest itself through differences in their migration behavior. If co-location pressure lies behind the concentration of power couples in large MSAs, it does not operate through couple migration. In this section, we argue that not only is co-location pressure not affecting the migration of power couples, but the migration of power couples is not likely to be important in affecting location patterns.

The observed location trends of power couples may arise through differences by city size in power couple migration, power couple formation - either through marriage or increased educational attainment-and/or power couple dissolution (divorce rates). ${ }^{13}$ Using the PSID and Census data we examine these dynamic processes.

\footnotetext{
${ }^{12}$ This suggestion depends on the assumption that individuals do not change occupations: the insignificance of the urban occupation indicators may be caused by individuals changing occupations following migration so that their occupation pre-migration is not indicative of their occupation post-migration.

${ }^{13}$ We ignore the dynamics of employment, although these are likely to differ by education and occupation. Basker (2003) develops a model of job search and migration that highlights the distinction between highly educated individuals, who tend to search first and then migrate, and less educated individuals, who tend to migrate without a job and then search.
} 


\subsection{Migration}

The overall migration patterns of couples and unmarried individuals reported in table 6 are broadly consistent with the predictions of human capital theory. ${ }^{14}$ Higher skilled individuals are more mobile than lower skilled individuals, power couples are more likely to migrate than are low- and part-power couples, and power singles are more likely to migrate than are low-power singles. The observed patterns are not consistent with Mincer's hypothesis that dual-career couples are less mobile than single-career couples.

The PSID transition data suggest that the migration of power couples is not the primary explanation for the increasing concentration of power couples in large MSAs - the migration patterns of power couples are not substantially different from those of power singles or part-power couples in which the husband has a college degree. There is, however, some evidence of a revealed preference for large MSAs among power couples. The average rate of migration of power couples living in large MSAs is lower than the rates of those living in medium and small MSAs, although the differences are not statistically significant. Among migrants, power couples are more likely to migrate to medium and large MSAs than to small MSAs. These trends, however, are not limited to power couples and may simply reflect a general preference for large urban areas. For every group considered, migration rates of those in the large areas are lower than the rates of those in small areas, and this difference is much larger, and statistically significant, for single power men and women. An unmarried man or woman with a college degree is much more likely to migrate from a small MSA than a power couple. Conditional on migration, single power men and single power women are also more likely to migrate to large MSAs than small MSAs, as are part-power couples in which the husband has a college degree. Low-power couples are more likely to migrate to smaller areas than larger and there is no statistically significant difference among the destination choices of part-power couples in which the wife has a college degree. The data suggest a revealed preference for large urban areas among college educated singles and among all couples in which the husband is college educated. Again we see the need to

\footnotetext{
${ }^{14}$ Recent immigrants are under-represented in the PSID sample. However the location patterns observed in the Census-those we are trying to explain--remain when immigrants are excluded from the Census sample.
} 
distinguish between the two types of part-power couples: those in which the husband is college educated and those in which the wife is college educated.

\subsection{Education by City Size}

The proportion of power couples in large MSAs may have increased simply because individuals living in large MSAs have a greater incentive to invest in human capital than those living in small MSAs. ${ }^{15}$ The wage premium that is earned by workers in large urban areas may be a compensating differential to offset higher living costs and urban disamenities but must also be due in part to higher productivity of workers in MSAs. Without higher productivity, it is difficult to explain why firms are willing to locate in these high-wage areas. The causes of this higher productivity may lie in the ability of MSAs to attract more able workers, or because MSAs create more productive workers by inducing human capital accumulation and labor-market matching. Glaeser and Maré (2001) investigate this question using a variety of data sources and argue that the urban wage premium is due to a combination of wage-level effects and wage-growth effects. They find that recent migrants to MSAs do experience real wage gains, but that the wage premium is highest for long-term residents of MSAs. Thus many of the urban wage gains accrue over time as urban workers accumulate more human capital and benefit from the better coordination of urban labor markets.

Table 7, which shows the proportion of high school graduates without college degrees currently enrolled in higher education, is consistent with this hypothesis. These data are from the integrated public use samples (IPUMS) of the U.S. Census for 1980, 1990 and 2000. The IPUMS samples are 1-in-100 national random samples of the U.S. population created by the Census Bureau as part of each decennial enumeration (Ruggles and Sobeck, 1997). The individual level records of the IPUMS samples include information on age, location, marital status, education and current education enrolment. The samples also allow the linkage of spousal records enabling us to determine the joint profile of married couples. With a few minor exceptions, the probability of being enrolled in education increases with population size for all groups in

${ }^{15}$ Glaeser (1999) suggests that urban density may increase interactions with highly skilled role models and facilitate coordination, thus increasing the demand for human capital. 
each year. ${ }^{16}$ For example in 1990, among married men with high-school diplomas, $6.3 \%$ of those living in small MSAs were enrolled in credit courses compared to $9.0 \%$ of those living in the largest MSAs, those with populations over five million.

The differences across city size indicate that the formation of power couples and power singles through educational attainment is more likely in larger MSAs than in smaller MSAs. Holding marriage and migration constant, an increasing concentration of power couples in large MSAs would occur if the proportion of married individuals in large MSAs who are enrolled in credit education is higher than the proportion of married individuals in smaller areas enrolled in credit education. For both married men and married women, the gap in enrollment rates between the large and small MSAs grew or remained constant between 1980 and 1990, and then fell between 1990 and 2000.

\subsection{Marriage and Divorce by City Size}

The relationship between city size and marriage is not straightforward. Edlund (2005) suggests that since large cities attract highly skilled individuals they also attract individuals (i.e., women) who seek to marry highly skilled individuals. Drewianka (2003) argues that marriage rates are affected not by the size of the city itself, but by the percentage of the adult population that is single. The effect is two-fold. With a relatively large single population, the probability of meeting a potential spouse whose quality exceeds a specified level in a given period of time is higher because people meet potential matches at a faster rate. But the large pool of potential matches also causes marriage market participants to increase their reservation quality level. Drewianka's empirical results suggest that the reservation quality effect dominates such that a $10 \%$ increase in the single population lowers the hazard rate for entering marriage between $7 \%$ and $10 \%$. Gould and Paserman (2003) find a strong negative relationship between women's marriage rates and the inequality of male wages within an urban area. They argue that higher levels of male wage inequality can explain $25 \%$ of the decline in marriage rates between 1970 and 1990 . Taken together, these papers suggest a

\footnotetext{
${ }^{16}$ The categories of small, midsize and large MSAs are different for this table than for the rest of the analyses because the public use files for 2000 do not identify places with populations less than 400,000 .
} 
finding similar to that of Robst and McGoldrick (1996) on the relationship between city size and labor market success: it is not the size of the market that is important, but its composition.

The human capital model of migration suggests a link between migration, city size, and marital instability. Increased labor force attachment of wives makes it more likely that the location preferences of spouses will differ which increases marital instability. This suggests two hypotheses. First, since power couples are more likely to experience co-location problems, they may be more likely to experience marital instability than part-power and low-power couples. Second, since co-location problems are less likely to occur in large labor markets, power couples living in small cities may have more marital breakups than those living in larger cities. Co-location problems may affect the location patterns observable in census data by increasing the relative stability of marriages in larger employment markets rather than by inducing migration.

Mincer (1978) notes that expectations of marital instability reduce the incentives for either spouse to become a tied-mover or tied-stayer, further amplifying marital instability. If we allow for expectations of marital instability, modeling migration as a response to maximizing net family benefits may be less satisfactory than modeling migration as a potentially inefficient bargaining solution to the co-location problem; these issues are more fully explored in Lundberg and Pollak (2003).

The results reported in table 8 suggest that the formation of power and part-power couples through marriage is more likely to occur in large urban areas compared to smaller urban areas. Table 8 shows the probability that an unmarried individual in year one will be married in year two, conditional on the size of the year two location. ${ }^{17}$ The probability of marriage decreases by city size for low-power singles, but there is no statistically significant difference in marriage rates among power singles of either sex. That is, power singles are just as likely to marry if they live in a large MSA or a small MSA, but low-power singles are more likely to marry in a small MSA. The patterns of assortative mating also suggest that power couples are more likely to be created in large MSAs than in small MSAs. While there is no clear differences in assortative mating patterns for women by city size, there is a more distinct relationship between assortative

\footnotetext{
${ }^{17}$ These are higher than might be expected for the total population because individuals in the sample must have been the head or spouse of a household at some point during the survey years, but this should not bias the comparison across city size.
} 
mating patterns and city size for men: college educated men living in small and midsize MSAs are as likely to marry a college educated spouse as a non-college educated spouse, i.e., those that marry are equally likely to create a part-power couple as a power couple. College educated men living in large MSAs, however, are more likely to marry college educated women than non-college educated women, i.e., conditional on marrying, the probability of creating a power couple from that marriage is greater than $50 \%$.

Finally, we consider the probability that a couple will divorce by city size. While the confidence intervals on these data are too large to make any definitive statements, the differences in the means shown in table 9 suggest that power couples are less likely to divorce than low-power couples. Furthermore, lowpower couples are more likely to divorce if they live in large metropolitan areas than in small MSAs, whereas power couples are more likely to divorce if they live in a small city. These estimates, while not precise, suggest that the stability of power couple marriages may be higher in large MSAs.

\section{The Decline in Power Couple Concentration in 2000}

Finally, we extend the time span of the census-based location analysis of Costa and Khan by using data from the 2000 census, data unavailable to Costa and Kahn. Table 10 shows the proportions of power, part-power and low-power couples living in large MSAs in each of the four census years $(1970,1980,1990$, 2000), using the 1990 MSA definitions for all years.

Since our regression results clearly show that the gender of the college-educated spouse matters for migration behavior, we separate part-power couples by which spouse holds a college degree. The data show that the proportions of couples living in large MSAs are lower when the wife is more highly educated than when the husband is more highly educated. The data also show that between 1970 and 1990, the proportion of power couples living in large MSAs increased dramatically, as noted by Costa and Kahn. However, the rising trend in concentration did not continue to 2000. Between 1990 and 2000 the proportion of power couples and part-power couples living in large MSAs declined, while the proportion of low-power couples living in large MSAs increased. 
Can either of the two hypotheses put forth to explain the rising concentration of power couples in large MSAs also explain the fall? Trends in women's labor supply did not reverse during this decade: labor force participation of married women remained steady between 1990 and 2000 and the proportion of women in specialized professional occupations increased during the decade. ${ }^{18}$ This suggests that the co-location pressure facing power couples did not weaken over this decade. But neither do we see evidence of a weakening of the relative attractiveness of large MSAs for the college educated. The fall in the proportion of power couples living in large MSAs was not mimicked in the category of power singles. and the proportions of both college educated single men and college educated single women living in large MSAs increased modestly between 1990 and 2000 (from 55.1 to 55.5 and from 54.2 to 54.6, respectively).

\section{Conclusion}

Using census data, Costa and Kahn (2000) show that between 1970 and 1990 couples in which both spouses were college graduates ("power couples") were increasingly likely to be located in the largest metropolitan areas. Costa and Kahn argued that these changes in location patterns were driven by the migration of power couples trying to solve their co-location problem -- a plausible-sounding hypothesis to anyone familiar with academic job markets.

In this paper we investigate the dynamic processes underlying the changes in location patterns found by Costa and Kahn. Using data from the Panel Study of Income Dynamics (PSID), we find that power couples are not more likely to migrate to the largest metropolitan areas and are no less likely than other couples to migrate from such areas once they are there. The dynamic processes that appear to contribute most to the observed trends in location patterns include: (i) the

\footnotetext{
18 The labor force participation rate of married women, aged $23-55$ increased from $43.5 \%$ in 1970 to $58.0 \%$ in $1980,70.8 \%$ in 1990 , and $70.9 \%$ in 2000 . The labor force participation rates for most subgroups - married women with and without young children, married women with and without college education - follow the same pattern, with a slight decline in the LFP rates between 1990 and 2000 for most groups (less than 1 percentage point fall). Calculations by authors using the census integrated public use census samples (Ruggles and Sobeck 1997).
} 
migration of power singles to large metropolitan areas, (ii) differences in rates of marriage and divorce of men and women with and without college degrees in cities of various sizes, (iii) and differences in the likelihood that individuals acquire additional education in cities of various sizes. The observed trends in location patterns are primarily due to differences in the rates at which power couples form and dissolve in cities of various sizes rather than to the migration of power couples to the largest metropolitan areas.

Our analysis of the PSID migration data hinges on our analysis of the behavior of partpower couples. Unlike Costa and Kahn, who group couples by the number of spouses with a college degree -- power, part-power, and low-power couples -- we decompose part-power couples into two subcategories: those in which only the husband has a college degree and those in which only the wife has a college degree. We find that couple migration patterns are determined by the husband's education profile, not by the couple's joint education profile. The migration patterns of couples in which both spouses have college degrees look like those of part-power couples in which only the husband has a college degree. The migration patterns of part-power couples in which only the wife has a college degree look like those of low-power couples.

Our conclusion that trends in location patterns are not generated by power couples migrating to solve their co-location problem is strengthened by data from the 2000 census. The 2000 census shows a decline in power couple concentration between 1990 and 2000 -- a decline that is difficult to reconcile with the co-location hypothesis.

The plausible-sounding hypothesis based on academic job markets is misleading because the typical power couple is not one $\mathrm{PhD}$ married to another $\mathrm{PhD}$, but a high school teacher married to a nurse. These more typical power couples do not need to locate in New York or Los Angeles to 
solve their co-location problem. But even when we look at super-power couples we find no support for the co-location hypothesis. 
Table 1 - Effect of Power Status on Probability of Migrating: Testing Sample Selection

\begin{tabular}{|c|c|c|c|c|c|c|}
\hline & $\begin{array}{l}\text { Probit: } \\
\text { Without } \\
\text { Sample } \\
\text { Selection } \\
\text { Controls }\end{array}$ & Tests & $\begin{array}{l}\text { Probit: } \\
\text { Sample }\end{array}$ & ction & $\begin{array}{l}\text { Maximum } \\
\text { Likelihood } \\
\text { Estimation }\end{array}$ & $\begin{array}{c}\text { ML } \\
\text { Estimation } \\
\text { without Past } \\
\text { Behavior } \\
\text { Variables }\end{array}$ \\
\hline & $(\mathrm{A})$ & (B) & (C) & (D) & (E) & $(\mathrm{F})$ \\
\hline $\begin{array}{l}\text { Power: Both spouses have } \\
\text { college degrees }\end{array}$ & $\begin{array}{c}0.378 \\
(0.060)\end{array}$ & $\begin{array}{c}0.363 \\
(0.085)\end{array}$ & $\begin{array}{c}0.396 \\
(0.076)\end{array}$ & $\begin{array}{l}0.346 \\
(0.084)\end{array}$ & $\begin{array}{c}0.383 \\
(0.059)\end{array}$ & $\begin{array}{c}0.199 \\
(0.177)\end{array}$ \\
\hline $\begin{array}{l}\text { Half Power: Only one spouse has } \\
\text { a college degree }\end{array}$ & $\begin{array}{c}0.245 \\
(0.000)\end{array}$ & $\begin{array}{c}0.249 \\
(0.080)\end{array}$ & $\begin{array}{c}0.266 \\
(0.078)\end{array}$ & $\begin{array}{c}0.218 \\
(0.073)\end{array}$ & $\begin{array}{c}0.254 \\
(0.053)\end{array}$ & $\begin{array}{c}0.095 \\
(0.122)\end{array}$ \\
\hline Origin - Midsize MSA & $\begin{array}{l}-0.018 \\
(0.045)\end{array}$ & $\begin{array}{l}-0.016 \\
(0.045)\end{array}$ & $\begin{array}{l}-0.018 \\
(0.045)\end{array}$ & $\begin{array}{l}-0.017 \\
(0.045)\end{array}$ & $\begin{array}{l}-0.019 \\
(0.044)\end{array}$ & $\begin{array}{l}-0.020 \\
(0.030)\end{array}$ \\
\hline Origin - Large MSA & $\begin{array}{l}-0.165 \\
(0.065)\end{array}$ & $\begin{array}{l}-0.162 \\
(0.066)\end{array}$ & $\begin{array}{l}-0.165 \\
(0.065)\end{array}$ & $\begin{array}{l}-0.163 \\
(0.065)\end{array}$ & $\begin{array}{l}-0.163 \\
(0.064)\end{array}$ & $\begin{array}{l}-0.094 \\
(0.058)\end{array}$ \\
\hline $\begin{array}{l}\text { Currently residing in home state } \\
\text { of at least one spouse }\end{array}$ & $\begin{array}{l}-0.543 \\
(0.040)\end{array}$ & $\begin{array}{c}-0.542 \\
(0.040)\end{array}$ & $\begin{array}{l}-0.543 \\
(0.040)\end{array}$ & $\begin{array}{r}-0.543 \\
(0.040)\end{array}$ & $\begin{array}{l}-0.531 \\
(0.043)\end{array}$ & \\
\hline $\begin{array}{l}\text { Head has previously moved for a } \\
\text { Job }\end{array}$ & $\begin{array}{c}0.092 \\
(0.044)\end{array}$ & $\begin{array}{c}0.094 \\
(0.045)\end{array}$ & $\begin{array}{c}0.093 \\
(0.044)\end{array}$ & $\begin{array}{c}0.092 \\
(0.045)\end{array}$ & $\begin{array}{c}0.090 \\
(0.044)\end{array}$ & \\
\hline $\begin{array}{l}\lambda_{1} \\
\lambda_{2}\end{array}$ & & $\begin{array}{c}-0.511 \\
(1.129) \\
1.157 \\
(1.163)\end{array}$ & & $\begin{array}{l}-0.645 \\
(1.114)\end{array}$ & & \\
\hline$\lambda_{3}$ & & & $\begin{array}{c}0.389 \\
(1.086)\end{array}$ & & & \\
\hline 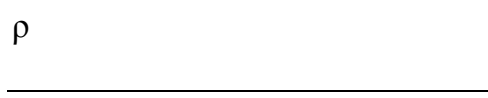 & & & & & $\begin{array}{c}0.478 \\
(0.511)\end{array}$ & $\begin{array}{l}-0.891 \\
(0.151)\end{array}$ \\
\hline $\begin{array}{l}\text { Wald test of independent } \\
\text { equations }(\rho=0) \\
\text { Test Statistic: } \chi^{2}(1) \\
\text { Prob }>\chi^{2} \\
\end{array}$ & & & & & $\begin{array}{c}0.62 \\
0.432 \\
\end{array}$ & $\begin{array}{c}3.76 \\
0.052 \\
\end{array}$ \\
\hline
\end{tabular}

Coefficients and standard errors presented. Standard errors are adjusted for clustering on household identifier.

Bold coefficients are significant at the $5 \%$ confidence level. 
Table 2- Binary Model: Probability of Migration

\begin{tabular}{|c|c|c|c|c|}
\hline & A & B & C & D \\
\hline Power: Both spouses have college degree & $\begin{array}{c}0.022 \\
(0.000)\end{array}$ & $\begin{array}{c}0.022 \\
(0.000)\end{array}$ & & $\begin{array}{c}0.026 \\
(\mathbf{0 . 0 1 0})\end{array}$ \\
\hline Half Power: Only one spouse has a college degree & $\begin{array}{c}0.013 \\
(0.000)\end{array}$ & & & \\
\hline Husband Power: Only husband has college degree & & $\begin{array}{c}0.020 \\
(0.000)\end{array}$ & & $\begin{array}{c}0.021 \\
(0.027)\end{array}$ \\
\hline Wife Power: Only wife has college degree & & $\begin{array}{c}0.001 \\
(0.786)\end{array}$ & & $\begin{array}{l}-0.016 \\
(0.126)\end{array}$ \\
\hline Husband Power2: Husband has a college degree & & & $\begin{array}{c}0.019 \\
(0.000)\end{array}$ & \\
\hline Wife Power2: Wife has a college degree & & & $\begin{array}{c}0.001 \\
(0.614)\end{array}$ & \\
\hline Origin - Midsize MSA & $\begin{array}{l}-0.001 \\
(0.666)\end{array}$ & $\begin{array}{l}-0.001 \\
(0.685)\end{array}$ & $\begin{array}{l}-0.001 \\
(0.686)\end{array}$ & $\begin{array}{l}-0.001 \\
(0.697)\end{array}$ \\
\hline Origin - Large MSA & $\begin{array}{l}-0.007 \\
(0.011)\end{array}$ & $\begin{array}{l}-0.007 \\
(0.012)\end{array}$ & $\begin{array}{l}-0.007 \\
(0.012)\end{array}$ & $\begin{array}{l}-0.013 \\
(0.015)\end{array}$ \\
\hline Power*Large MSA & & & & $\begin{array}{l}-0.007 \\
(0.491)\end{array}$ \\
\hline Husband Power*Large MSA & & & & $\begin{array}{l}-0.002 \\
(0.857)\end{array}$ \\
\hline Wife Power*Large MSA & & & & $\begin{array}{c}0.057 \\
(0.052)\end{array}$ \\
\hline $\begin{array}{l}\text { Currently residing in home state of at least } \\
\text { one spouse }\end{array}$ & $\begin{array}{l}-0.022 \\
(0.000)\end{array}$ & $\begin{array}{c}-0.021 \\
(0.000)\end{array}$ & $\begin{array}{l}-0.022 \\
(0.000)\end{array}$ & $\begin{array}{l}-0.044 \\
(0.000)\end{array}$ \\
\hline Head has previously moved for a job & $\begin{array}{c}0.004 \\
(0.045)\end{array}$ & $\begin{array}{c}0.004 \\
(0.047)\end{array}$ & $\begin{array}{c}0.004 \\
(0.049)\end{array}$ & $\begin{array}{c}0.008 \\
(0.058)\end{array}$ \\
\hline$\rho^{*}$ & $\begin{array}{c}0.478 \\
(0.511)\end{array}$ & $\begin{array}{c}0.533 \\
(0.376)\end{array}$ & $\begin{array}{l}0.511 \\
(0490)\end{array}$ & $\begin{array}{l}-0.807 \\
(0.181) \\
\end{array}$ \\
\hline
\end{tabular}

Wald Coefficient Tests (Prob $\left.>\chi^{2}\right)$

Power $=$ Half Power $\quad 0.054$

Power $=$ Husband Power

0.707

Power $=$ Wife Power

$0.000 \quad 0.004$

Husband Power $=$ Wife Power

0.001

0.005

Husband Power2=Wife Power2

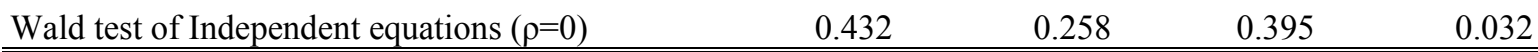

0.000

For ease of interpretation, the marginal effects of the variables are presented. For the dummy variables, this is dy/dx for a discrete change of dummy variable from 0 to $1 . \quad \mathrm{P}>|\mathrm{z}|$ in parentheses. For $\rho$, the coefficient is given, with its standard error in parentheses. Standard errors are adjusted for clustering on household identifier. Bold coefficients are significant at the $95 \%$ confidence level or higher. 
Table 3a - Multinomial Logit Model: Probability of Migrating to (small, medium, large) Destination

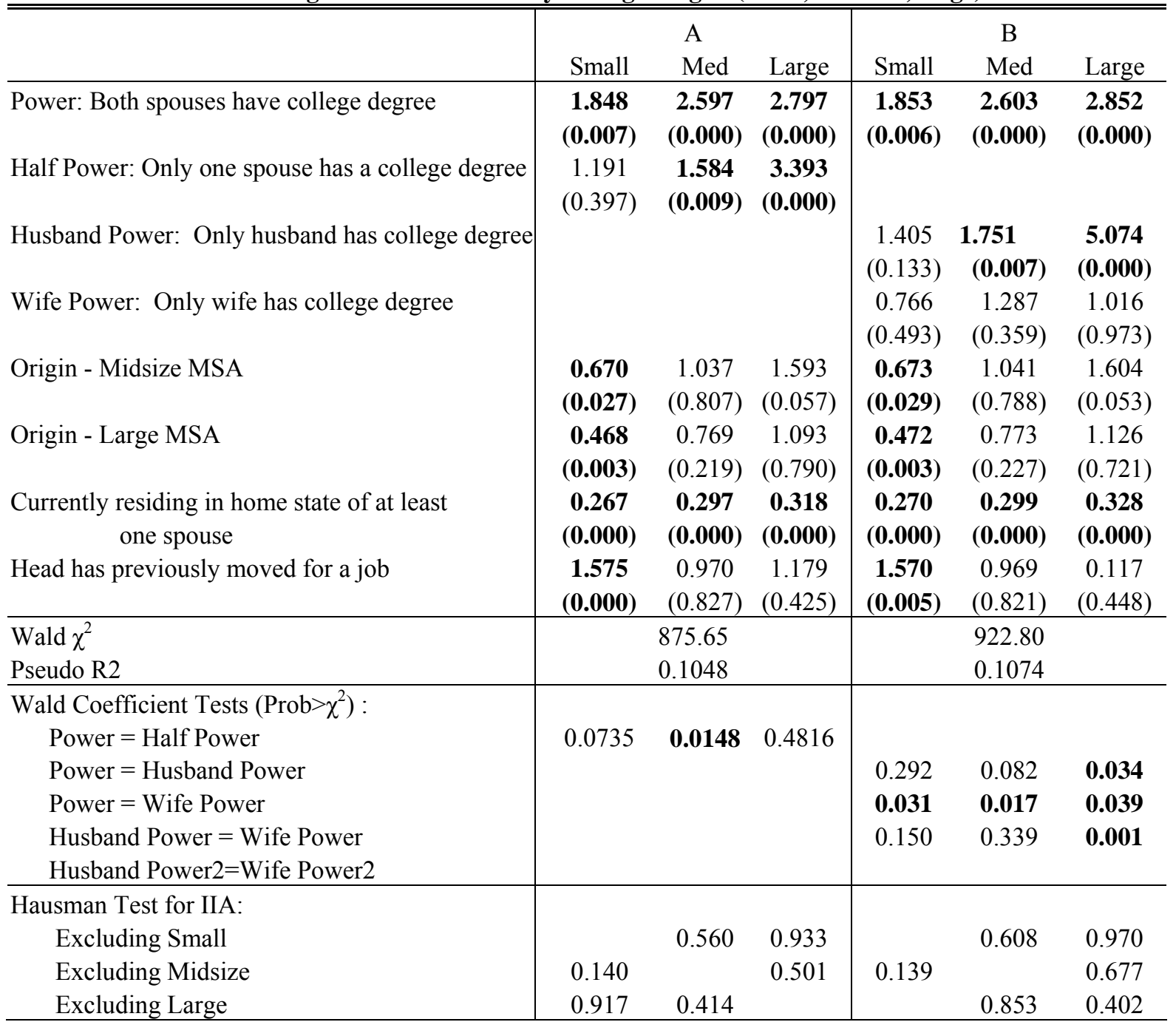

The coefficients are presented as relative risk ratios. For dummy variables, this is the change in the ratio of the probability of migrating to the indicated destination size and the probability of not migrating due to a discrete change in the variable from 0 to 1 . $\quad \mathrm{P}>|\mathrm{z}|$ in parentheses. Standard errors are adjusted for clustering on household identifier. Bold coefficients are significant at the $95 \%$ confidence level or higher. 
Table 3b - Multinomial Logit Model: Probability of Migrating to (small, medium, large) Destination

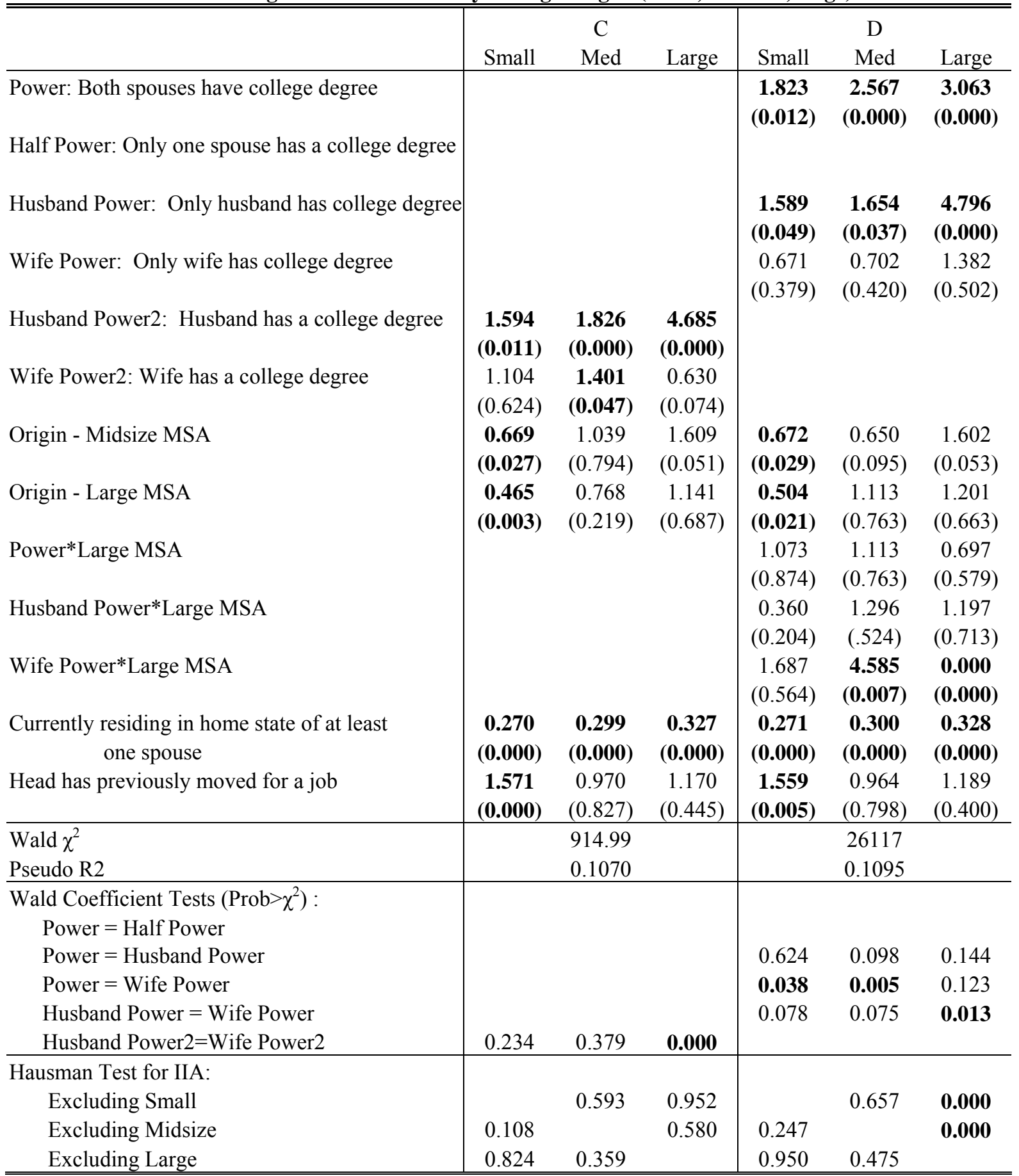

The coefficients are presented as relative risk ratios. For dummy variables, this is the change in the ratio of the probability of migrating to the indicated destination size and the probability of not migrating due to a discrete change in the variable from 0 to 1 . $\quad \mathrm{P}>|\mathrm{z}|$ in parentheses. Standard errors are adjusted for clustering on household identifier. Bold coefficients are significant at the $95 \%$ confidence level or higher. 
Table 4 - Binary Model: Probability of Migration Part II

\begin{tabular}{lcccc}
\hline \hline & $\mathbf{E}$ & $\mathbf{F}$ & $\mathbf{G}$ & $\mathbf{H}^{*}$ \\
\hline Power: Both spouses have college degree & $\mathbf{0 . 0 2 2}$ & $\mathbf{0 . 0 2 0}$ & $\mathbf{0 . 0 1 9}$ & $\mathbf{0 . 0 2 2}$ \\
& $\mathbf{( 0 . 0 0 0 )}$ & $\mathbf{( 0 . 0 0 0 )}$ & $\mathbf{( 0 . 0 0 0}$ & $\mathbf{( 0 . 0 0 0}$ \\
Husband Power: Only husband has college degree & $\mathbf{0 . 0 2 0}$ & $\mathbf{0 . 0 1 9}$ & $\mathbf{0 . 0 1 9}$ & $\mathbf{0 . 0 2 0}$ \\
& $\mathbf{( 0 . 0 0 0 )}$ & $\mathbf{( 0 . 0 0 0 )}$ & $\mathbf{( 0 . 0 0 0 )}$ & $\mathbf{( 0 . 0 0 0 )}$ \\
Wife Power: Only wife has college degree & -0.0002 & 0.001 & 0.001 & 0.001 \\
& $(0.956)$ & $(0.840)$ & $(0.877)$ & $(0.909)$ \\
Percentage of husband occupation in large MSA & 0.004 & & \\
Percentage of wife occupation in large MSA & $(0.661)$ & & \\
& -0.009 & & \\
Both spouses have urban occupations & $(0.514)$ & 0.004 & \\
& & & \\
Only husband has urban occupation & & $\mathbf{0 . 0 0 5}$ & \\
& & $\mathbf{0 . 0 3 7}$ & \\
Only wife has urban occupation & & 0.005 \\
\end{tabular}

At least one spouse has advanced degree

0.004

$(0.251)$

Both spouses have advanced degrees

$-0.003$

$(0.653)$

0.005

Only husband has advanced degree

$(0.266)$

Only wife has advanced degree

0.004

Origin - Midsize MSA

$-0.001$

$(0.537)$

Origin - Large MSA

$(0.645)$

$-0.001$

$-0.001$

$-\mathbf{0 . 0 0 7}$

(0.629)

$-0.001$

$(0.724)$

Currently residing in home state of at least

$(0.009)$

$-0.006$

$(0.718)$

$-0.007$

$-0.022$

(0.015)

$-0.006$

(0.008)

one spouse

(0.000)

$-0.021$

(0.016)

$-0.035$

0.004

(0.000)

$-0.022$

(0.000)

Head has previously moved for a job

(0.041)

0.004

(0.000)

0.005

(0.044)

0.004

(0.047)

$\rho^{*}$

0.585

0.631

(0.042)

$(0.240)$

$(0.172)$

0.569

Wald Coefficient Tests (Prob $\left.>\chi^{2}\right)$

Power $=$ Half Power

0.785

0.732

$(0.650)$

Power $=$ Husband Power

0.0001

0.001

0.972

0.758

Power $=$ Wife Power

0.0004

0.002

0.002

0.001

0.002

0.005

Wald test of Independent equations $(\rho=0)$

0.067

0.010

0.381

For ease of interpretation, the marginal effects of the variables are presented. For the dummy variables, this is dy/dx for a discrete change of dummy variable from 0 to 1 . $P>|z|$ in parentheses. For $\rho$, the coefficient is given, with its standard error in parentheses. Standard errors are adjusted for clustering on household identifier. Bold coefficients are significant at the $95 \%$ confidence level or higher.

Due to convergence problems, the regression in column $\mathrm{H}$ is run as a single probit, without correcting for sample selection. 
Table 5a - Multinomial Logit Model: Probability of Migrating to (small, medium, large) Destination Size

\begin{tabular}{|c|c|c|c|c|c|c|}
\hline & \multicolumn{3}{|c|}{$\mathrm{E}$} & \multicolumn{3}{|c|}{$\mathrm{F}$} \\
\hline & Small & Med & Large & Small & Med & Large \\
\hline Power: Both spouses have college degree & $\begin{array}{c}1.798 \\
(0.012)\end{array}$ & $\begin{array}{c}2.574 \\
(0.000)\end{array}$ & $\begin{array}{c}2.960 \\
(0.000)\end{array}$ & $\begin{array}{c}1.753 \\
(0.016)\end{array}$ & $\begin{array}{c}2.441 \\
(0.000)\end{array}$ & $\begin{array}{c}2.914 \\
(0.000)\end{array}$ \\
\hline Husband Power: Only husband has college degree & $\begin{array}{c}1.414 \\
(0.128)\end{array}$ & $\begin{array}{c}1.758 \\
(0.007)\end{array}$ & $\begin{array}{c}5.226 \\
(0.000)\end{array}$ & $\begin{array}{c}1.361 \\
(0.181)\end{array}$ & $\begin{array}{l}1.629 \\
(0.018)\end{array}$ & $\begin{array}{c}5.178 \\
(0.000)\end{array}$ \\
\hline Wife Power: Only wife has college degree & $\begin{array}{c}0.532 \\
(0.165)\end{array}$ & $\begin{array}{c}1.304 \\
(0.335)\end{array}$ & $\begin{array}{c}1.034 \\
(0.944)\end{array}$ & $\begin{array}{c}0.749 \\
(0.461)\end{array}$ & $\begin{array}{c}1.286 \\
(0.359)\end{array}$ & $\begin{array}{c}1.016 \\
(0.972)\end{array}$ \\
\hline Percentage of husband occupation in large MSA & $\begin{array}{c}0.629 \\
(0.544)\end{array}$ & $\begin{array}{c}1.469 \\
(0.562)\end{array}$ & $\begin{array}{c}0.773 \\
(0.818)\end{array}$ & & & \\
\hline Percentage of wife occupation in large MSA & $\begin{array}{c}6.914 \\
(0.103)\end{array}$ & $\begin{array}{c}0.232 \\
(0.113)\end{array}$ & $\begin{array}{c}0.152 \\
(0.298)\end{array}$ & & & \\
\hline Both spouses have urban occupations & & & & $\begin{array}{c}1.671 \\
(0.064)\end{array}$ & $\begin{array}{c}0.924 \\
(0.751)\end{array}$ & $\begin{array}{c}0.980 \\
(0.955)\end{array}$ \\
\hline Only husband has urban occupation & & & & $\begin{array}{c}1.144 \\
(0.527)\end{array}$ & $\begin{array}{c}1.516 \\
(0.005)\end{array}$ & $\begin{array}{c}0.881 \\
(0.614)\end{array}$ \\
\hline Only wife has urban occupation & & & & $\begin{array}{c}1.409 \\
(0.324)\end{array}$ & $\begin{array}{c}1.290 \\
(0.292)\end{array}$ & $\begin{array}{c}0.952 \\
(0.893)\end{array}$ \\
\hline Origin - Midsize MSA & $\begin{array}{c}0.655 \\
(0.020)\end{array}$ & $\begin{array}{c}1.049 \\
(0.743)\end{array}$ & $\begin{array}{c}1.637 \\
(0.046)\end{array}$ & $\begin{array}{c}0.674 \\
(0.030)\end{array}$ & $\begin{array}{c}1.025 \\
(0.867)\end{array}$ & $\begin{array}{c}1.613 \\
(0.052)\end{array}$ \\
\hline Origin - Large MSA & $\begin{array}{c}0.434 \\
(0.001)\end{array}$ & $\begin{array}{c}0.779 \\
(0.246)\end{array}$ & $\begin{array}{c}1.135 \\
(0.705)\end{array}$ & $\begin{array}{c}0.483 \\
(0.004)\end{array}$ & $\begin{array}{c}0.787 \\
(0.261)\end{array}$ & $\begin{array}{c}1.122 \\
(0.730)\end{array}$ \\
\hline $\begin{array}{l}\text { Currently residing in home state of at least } \\
\text { one spouse }\end{array}$ & $\begin{array}{c}0.276 \\
(0.000)\end{array}$ & $\begin{array}{c}0.299 \\
(0.000)\end{array}$ & $\begin{array}{c}0.329 \\
(0.000)\end{array}$ & $\begin{array}{c}0.270 \\
(0.000)\end{array}$ & $\begin{array}{c}0.298 \\
(0.000)\end{array}$ & $\begin{array}{c}0.329 \\
(0.000)\end{array}$ \\
\hline Head has previously moved for job & $\begin{array}{c}1.574 \\
(0.005)\end{array}$ & $\begin{array}{c}0.983 \\
(0.900) \\
\end{array}$ & $\begin{array}{c}1.171 \\
(0.440) \\
\end{array}$ & $\begin{array}{c}1.563 \\
(0.005)\end{array}$ & $\begin{array}{c}0.970 \\
(0.825) \\
\end{array}$ & $\begin{array}{r}1.170 \\
(0.445) \\
\end{array}$ \\
\hline $\begin{array}{l}\text { Wald } \chi^{2} \\
\text { Pseudo } \mathrm{R}^{2}\end{array}$ & $\begin{array}{l}924.39 \\
0.1083 \\
\end{array}$ & & & $\begin{array}{l}939.20 \\
0.1093\end{array}$ & & \\
\hline $\begin{array}{l}\text { Wald Coefficient Tests }\left(\text { Prob }>\chi^{2}\right): \\
\text { Power }=\text { Husband Power } \\
\text { Power }=\text { Wife Power } \\
\text { Husband Power }=\text { Wife Power }\end{array}$ & $\begin{array}{l}0.365 \\
0.010 \\
0.043\end{array}$ & $\begin{array}{l}\mathbf{0 . 0 1 0} \\
\mathbf{0 . 0 2 3} \\
0.353 \\
\end{array}$ & $\begin{array}{l}0.041 \\
0.038 \\
0.001 \\
\end{array}$ & $\begin{array}{c}0.3411 \\
\mathbf{0 . 0 4 0} \\
0.162 \\
\end{array}$ & $\begin{array}{l}0.074 \\
\mathbf{0 . 0 3 3} \\
0.462 \\
\end{array}$ & $\begin{array}{l}0.039 \\
0.037 \\
0.001 \\
\end{array}$ \\
\hline $\begin{array}{l}\text { Hausman Test for IIA: } \\
\qquad \begin{array}{l}\text { Excluding Small } \\
\text { Excluding Midsize } \\
\text { Excluding Large } \\
\end{array}\end{array}$ & $\begin{array}{l}0.222 \\
0.756 \\
\end{array}$ & 0.510 & $\begin{array}{l}0.924 \\
0.746\end{array}$ & $\begin{array}{l}0.184 \\
0.780 \\
\end{array}$ & $\begin{array}{l}0.474 \\
0.215 \\
\end{array}$ & $\begin{array}{l}0.974 \\
0.633\end{array}$ \\
\hline
\end{tabular}

The coefficients are presented as relative risk ratios. For dummy variables, this is the change in the ratio of the probability of migrating to the indicated destination size and the probability of not migrating due to a discrete change in the variable from 0 to $1 . \quad P>|z|$ in parentheses. Standard errors are adjusted for clustering on household identifier. Bold coefficients are significant at the $95 \%$ confidence level or higher. 
Table 5b - Multinomial Logit Model: Probability of Migrating to (small, medium, large) Destination Size

\begin{tabular}{|c|c|c|c|c|c|c|}
\hline \multirow[t]{2}{*}{ Married Sample } & \multicolumn{3}{|c|}{$\mathrm{G}$} & \multicolumn{3}{|c|}{$\mathrm{H}$} \\
\hline & Small & Med & Large & Small & Med & Large \\
\hline Power: Both spouses have college degree & $\begin{array}{l}1.505 \\
(0.111)\end{array}$ & $\begin{array}{c}2.759 \\
(0.000)\end{array}$ & $\begin{array}{c}2.176 \\
(0.015)\end{array}$ & $\begin{array}{c}1.520 \\
(0.103)\end{array}$ & $\begin{array}{c}2.758 \\
(0.000)\end{array}$ & $\begin{array}{c}2.304 \\
(0.008)\end{array}$ \\
\hline Husband Power: Only husband has college degree & $\begin{array}{c}1.275 \\
(0.308)\end{array}$ & $\begin{array}{c}1.800 \\
(0.007)\end{array}$ & $\begin{array}{c}4.511 \\
(0.000)\end{array}$ & $\begin{array}{c}1.253 \\
(0.355)\end{array}$ & $\begin{array}{c}1.811 \\
(0.006)\end{array}$ & $\begin{array}{c}4.400 \\
(0.000)\end{array}$ \\
\hline Wife Power: Only wife has college degree & $\begin{array}{c}0.728 \\
(0.411)\end{array}$ & $\begin{array}{c}1.301 \\
(0.336)\end{array}$ & $\begin{array}{c}0.953 \\
(0.920)\end{array}$ & $\begin{array}{c}0.745 \\
(0.441)\end{array}$ & $\begin{array}{c}1.280 \\
(0.364)\end{array}$ & $\begin{array}{c}0.958 \\
(0.929)\end{array}$ \\
\hline At least one spouse has advanced degree & $\begin{array}{c}1.559 \\
(0.087)\end{array}$ & $\begin{array}{c}0.873 \\
(0.545)\end{array}$ & $\begin{array}{c}1.715 \\
(0.079)\end{array}$ & & & \\
\hline Both spouses have advanced degrees & & & & $\begin{array}{c}1.459 \\
(0.506)\end{array}$ & $\begin{array}{c}0.784 \\
(0.638)\end{array}$ & $\begin{array}{c}0.525 \\
(0.523)\end{array}$ \\
\hline Only husband has advanced degree & & & & $\begin{array}{c}1.662 \\
(0.076)\end{array}$ & $\begin{array}{c}0.831 \\
(0.466)\end{array}$ & $\begin{array}{c}1.866 \\
(0.050)\end{array}$ \\
\hline Only wife has advanced degree & & & & $\begin{array}{l}1.310 \\
(0.563)\end{array}$ & $\begin{array}{c}1.047 \\
(0.899)\end{array}$ & $\begin{array}{c}1.625 \\
(0.335)\end{array}$ \\
\hline Origin - Midsize MSA & $\begin{array}{c}0.682 \\
(0.034)\end{array}$ & $\begin{array}{c}1.037 \\
(0.804)\end{array}$ & $\begin{array}{c}1.636 \\
(0.045)\end{array}$ & $\begin{array}{c}0.682 \\
(0.034)\end{array}$ & $\begin{array}{c}1.035 \\
(0.813)\end{array}$ & $\begin{array}{c}1.626 \\
(0.048)\end{array}$ \\
\hline Origin - Large MSA & $\begin{array}{c}0.487 \\
(0.005)\end{array}$ & $\begin{array}{c}0.765 \\
(0.210)\end{array}$ & $\begin{array}{c}1.181 \\
(0.621)\end{array}$ & $\begin{array}{c}0.486 \\
(0.005)\end{array}$ & $\begin{array}{c}0.762 \\
(0.203)\end{array}$ & $\begin{array}{c}1.156 \\
(0.667)\end{array}$ \\
\hline $\begin{array}{l}\text { Currently residing in home state of at least } \\
\text { one spouse }\end{array}$ & $\begin{array}{c}0.273 \\
(0.000)\end{array}$ & $\begin{array}{c}0.297 \\
(0.000)\end{array}$ & $\begin{array}{c}0.334 \\
(0.000)\end{array}$ & $\begin{array}{c}0.274 \\
(0.000)\end{array}$ & $\begin{array}{c}0.296 \\
(0.000)\end{array}$ & $\begin{array}{c}0.335 \\
(0.000)\end{array}$ \\
\hline Head has previously moved for job & $\begin{array}{c}1.590 \\
(0.004)\end{array}$ & $\begin{array}{c}0.961 \\
(0.773)\end{array}$ & $\begin{array}{l}1.202 \\
(0.371)\end{array}$ & $\begin{array}{l}1.598 \\
(0.004)\end{array}$ & $\begin{array}{c}0.957 \\
(0.749)\end{array}$ & $\begin{array}{c}1.200 \\
(0.375)\end{array}$ \\
\hline $\begin{array}{l}\text { Wald } \chi^{2} \\
\text { Pseudo R }\end{array}$ & $\begin{array}{l}946.12 \\
0.1084\end{array}$ & & & $\begin{array}{l}963.37 \\
0.1088\end{array}$ & & \\
\hline $\begin{array}{l}\text { Wald Coefficient Tests }\left(\text { Prob }>\chi^{2}\right) \text { : } \\
\text { Power }=\text { Husband Power }\end{array}$ & & & & & & \\
\hline Power $=$ Wife Power & 0.088 & 0.017 & $\begin{array}{l}0.014 \\
0.111\end{array}$ & $\begin{array}{l}0.401 \\
0.093\end{array}$ & 0.013 & $\begin{array}{l}0.050 \\
0.087\end{array}$ \\
\hline Husband Power $=$ Wife Power & 0.187 & 0.324 & 0.001 & 0.221 & 0.284 & 0.002 \\
\hline $\begin{array}{l}\text { Hausman Test for IIA: } \\
\text { Excluding Small }\end{array}$ & & 0.673 & 0.970 & & 0.706 & 0.978 \\
\hline $\begin{array}{l}\text { Excluding Midsize } \\
\text { Excluding Large }\end{array}$ & $\begin{array}{l}0.197 \\
0.792\end{array}$ & 0.322 & 0.725 & $\begin{array}{l}0.148 \\
0.855\end{array}$ & 0.419 & 0.750 \\
\hline
\end{tabular}

$\overline{\text { The coefficients are presented as relative risk ratios. For dummy variables, this is the change in the ratio of the probability of migrating to the }}$ indicated destination size and the probability of not migrating due to a discrete change in the variable from 0 to 1 . $\quad \mathrm{P}>|\mathrm{z}|$ in parentheses. Standard errors are adjusted for clustering on household identifier. Bold coefficients are significant at the $95 \%$ confidence level or higher. 


\begin{tabular}{|c|c|c|c|c|c|c|}
\hline & \multirow{2}{*}{\multicolumn{3}{|c|}{$\begin{array}{l}\text { Probability of Migrating } \\
\text { 95\% Confidence }\end{array}$}} & \multirow{2}{*}{\multicolumn{3}{|c|}{$\begin{array}{l}\text { Destination, Conditional on } \\
\text { Migrating } \\
\mathbf{9 5 \%} \text { Confidence }\end{array}$}} \\
\hline & & & & & & \\
\hline Power couple & Mean & Lower & Upper & Mean & Lower & Upper \\
\hline Small metropolitan area & 7.34 & 5.06 & 9.62 & 23.3 & 17.0 & 29.6 \\
\hline Midsize metropolitan area & 8.01 & 6.12 & 9.90 & 36.4 & 29.2 & 43.5 \\
\hline Large metropolitan area & 6.20 & 4.86 & 7.54 & 40.3 & 33.0 & 47.7 \\
\hline \multicolumn{7}{|l|}{ Part-Power couple: Husband has BA } \\
\hline Small metropolitan area & 5.67 & 3.79 & 7.55 & 20.0 & 13.2 & 26.8 \\
\hline Midsize metropolitan area & 9.61 & 7.23 & 11.99 & 39.3 & 30.9 & 47.6 \\
\hline Large metropolitan area & 4.83 & 3.45 & 6.21 & 40.7 & 32.3 & 49.1 \\
\hline \multicolumn{7}{|l|}{ Part-Power couple: Wife has BA } \\
\hline Small metropolitan area & 4.34 & 2.31 & 6.36 & 25.5 & 12.6 & 38.5 \\
\hline Midsize metropolitan area & 4.24 & 2.20 & 6.29 & 42.6 & 27.9 & 57.2 \\
\hline Large metropolitan area & 3.20 & 1.70 & 4.69 & 31.9 & 18.1 & 45.7 \\
\hline \multicolumn{7}{|l|}{ Low-Power couple } \\
\hline Small metropolitan area & 3.22 & 2.74 & 3.71 & 36.9 & 32.7 & 41.2 \\
\hline Midsize metropolitan area & 4.29 & 3.70 & 4.89 & 37.7 & 33.5 & 42.0 \\
\hline Large metropolitan area & 2.69 & 2.26 & 3.11 & 25.3 & 21.5 & 29.2 \\
\hline \multicolumn{7}{|l|}{ Single Power men } \\
\hline Small metropolitan area & 17.43 & 12.36 & 22.51 & 23.7 & 16.3 & 31.0 \\
\hline Midsize metropolitan area & 12.35 & 9.13 & 15.56 & 33.6 & 25.4 & 41.8 \\
\hline Large metropolitan area & 5.66 & 4.09 & 7.24 & 42.7 & 34.2 & 51.3 \\
\hline \multicolumn{7}{|l|}{ Single Power women } \\
\hline Small metropolitan area & 16.85 & 12.43 & 21.26 & 22.2 & 15.9 & 28.5 \\
\hline Midsize metropolitan area & 10.55 & 8.08 & 13.02 & 38.0 & 30.7 & 45.4 \\
\hline Large metropolitan area & 6.24 & 4.80 & 7.68 & 39.8 & 32.4 & 47.2 \\
\hline \multicolumn{7}{|l|}{ Single Low-Power men } \\
\hline Small metropolitan area & 8.14 & 6.88 & 9.41 & 33.2 & 28.4 & 37.9 \\
\hline Midsize metropolitan area & 5.27 & 4.34 & 6.20 & 31.1 & 26.4 & 35.7 \\
\hline Large metropolitan area & 4.65 & 4.01 & 5.30 & 35.8 & 30.9 & 40.6 \\
\hline \multicolumn{7}{|l|}{ Single Low-Power women } \\
\hline Small metropolitan area & 6.32 & 5.37 & 7.28 & 28.0 & 23.9 & 32.1 \\
\hline Midsize metropolitan area & 3.96 & 3.37 & 4.54 & 35.7 & 31.6 & 40.1 \\
\hline Large metropolitan area & 2.59 & 2.25 & 2.93 & 36.3 & 31.9 & 40.7 \\
\hline
\end{tabular}

Annual migration rates from 1970 to 1996 estimated from PSID sample. The estimates assume that the migration rates for each category remain constant for 1970-1996, but when we split the PSID sample into the three decades, we find no significant differences in the migration rates of power couples between the 1970s and 1980s nor between the 1970s and 1990s. Couples include those who are observed married or cohabiting in year one and year two. Singles are also limited to those who did not change marital status during the year. Large metropolitan areas are those with at least $2 \mathrm{M}$ population, midsize metropolitan areas have populations between 250,000 to $2 \mathrm{M}$, smaller metropolitan areas and counties that are not contained in a metropolitan area are included in the final category. Power couples are those in which both spouses have completed at least four years of college or hold college degrees, part-power couples include only one spouse with a college education, low-power couples are those in which neither spouse has a college degree. Couples are limited to those in which the wife was 23 to 37 years of age and the husband was 25 to 39 years of age. Singles fall into the same age categories. 
Table 7 - Percent of Population Who Have a High School Diploma but Not a College Degree Who Are Enrolled in Credit Education

\begin{tabular}{|c|c|c|c|c|c|}
\hline & 1980 & 1990 & 2000 & $\begin{array}{c}\text { \% Change } \\
80-90 \\
\end{array}$ & $\begin{array}{c}\% \text { Change } \\
90-00\end{array}$ \\
\hline \multicolumn{6}{|l|}{ Married Men } \\
\hline Non-MSA or MSA fewer than $1 \mathrm{M}$ & 5.6 & 6.3 & 6.6 & 11.8 & 5.4 \\
\hline MSA population between 1-2M & 8.5 & 8.3 & 8.9 & -2.1 & 6.6 \\
\hline MSA population over $2 \mathrm{M}$ & 8.2 & 9.0 & 8.2 & 9.8 & -8.6 \\
\hline \multicolumn{6}{|l|}{ Married Women } \\
\hline Non-MSA or MSA fewer than $1 \mathrm{M}$ & 5.0 & 8.0 & 7.8 & 58.8 & -2.6 \\
\hline MSA population between $1-2 \mathrm{M}$ & 6.8 & 9.1 & 8.5 & 34.1 & -6.8 \\
\hline MSA population over $2 \mathrm{M}$ & 7.1 & 10.0 & 9.5 & 40.5 & -4.9 \\
\hline \multicolumn{6}{|l|}{ Unmarried Men } \\
\hline Non-MSA or MSA fewer than $1 \mathrm{M}$ & 10.0 & 9.7 & 12.2 & -2.9 & 25.4 \\
\hline MSA population between $1-2 \mathrm{M}$ & 12.2 & 11.4 & 14.3 & -6.3 & 25.1 \\
\hline MSA population over $2 \mathrm{M}$ & 12.9 & 13.3 & 16.1 & 3.3 & 20.5 \\
\hline \multicolumn{6}{|l|}{ Unmarried Women } \\
\hline Non-MSA or MSA fewer than $1 \mathrm{M}$ & 11.5 & 13.9 & 15.3 & 21.5 & 9.7 \\
\hline MSA Population between 1-2M & 14.6 & 14.9 & 16.7 & 1.8 & 12.6 \\
\hline MSA population over $2 \mathrm{M}$ & 14.7 & 16.8 & 19.1 & 13.9 & 13.6 \\
\hline
\end{tabular}

Calculated by authors using the Census Integrated public use census samples (Ruggles and Sobeck 1997). 


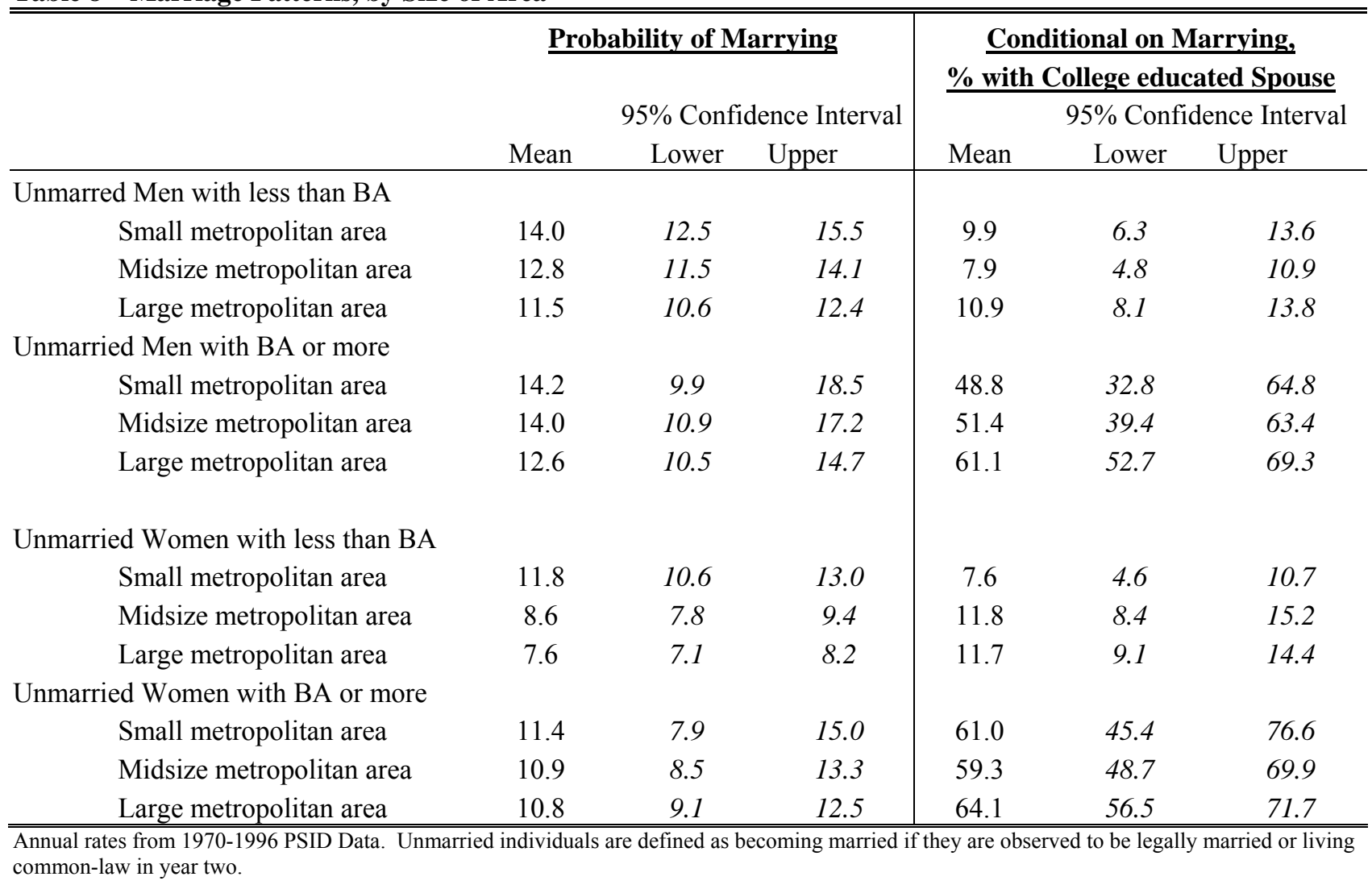

Table 9 - Probability of Marriage Breakup, by Size of Area

\begin{tabular}{|c|c|c|c|}
\hline & \multirow[t]{2}{*}{ Means } & \multicolumn{2}{|c|}{ 95\% Confidence Interval } \\
\hline & & Lower & Upper \\
\hline \multicolumn{4}{|l|}{ Power Couple } \\
\hline Small metropolitan area & 1.95 & 0.75 & 3.14 \\
\hline Midsize metropolitan area & 1.60 & 0.74 & 2.47 \\
\hline Large metropolitan area & 1.27 & 0.65 & 1.89 \\
\hline \multicolumn{4}{|l|}{ Part-Power Couple } \\
\hline Small metropolitan area & 2.50 & 1.53 & 3.47 \\
\hline Midsize metropolitan area & 2.61 & 1.62 & 3.60 \\
\hline Large metropolitan area & 1.81 & 1.13 & 2.49 \\
\hline \multicolumn{4}{|l|}{ Low-Power Couple } \\
\hline Small metropolitan area & 3.14 & 2.67 & 3.62 \\
\hline Midsize metropolitan area & 3.77 & 3.22 & 4.32 \\
\hline Large metropolitan area & 4.01 & 3.50 & 4.52 \\
\hline
\end{tabular}


Table 10 - Proportion of Household Groups Living in MSAs Greater Than 2 Million

\begin{tabular}{lcccc}
\hline \hline & $\mathbf{1 9 7 0}$ & $\mathbf{1 9 8 0}$ & $\mathbf{1 9 9 0}$ & $\mathbf{2 0 0 0}$ \\
\hline Power Couple & 40.1 & 43.3 & 49.7 & 46.9 \\
& & & & \\
Part-Power Couple & 37.1 & 37.3 & 40.1 & 38.2 \\
$\quad$ Part-Power - Husband has college degree & 38.6 & 40.1 & 42.6 & 41.1 \\
$\quad$ Part-Power - Wife has college degree & 35.3 & 34.9 & 37.9 & 37.1 \\
& & & & \\
Low Power Couple & 31.2 & 32.3 & 31.3 & 33.5 \\
& & & & \\
Single power men & 51.3 & 53.4 & 55.1 & 55.5 \\
Single power women & 48.5 & 53.4 & 54.2 & 54.6 \\
& & & & \\
Single low-power men & 38.7 & 42.3 & 39.8 & 40.2 \\
Single low-power women & 39.9 & 44.2 & 40.8 & 41.1 \\
& & & & \\
All couples in age range & 32.9 & 35.0 & 35.7 & 37.3 \\
All single men in age range & 40.8 & 45.4 & 43.2 & 44.0 \\
All single women in age range & 41.1 & 46.3 & 43.9 & 44.9 \\
\hline \hline
\end{tabular}

Power couples are those in which both spouses have completed at least four years of college or hold college degrees, part-power couples include those couples in which only one spouse has completed at least four years of college or holds a college degree, low-power couples are those in which neither spouse has four years of college or a college degree. Couples are limited to legally married couples residing in the same household. For married couples, the sample is limited to those in which the wife was 23 to 37 years of age and the husband was 25 to 39 years of age. Singles fall into the same age categories. Calculations by authors using the census integrated public use census samples (Ruggles and Sobeck 1997). 


\section{BIBLIOGRAPHY}

Basker, Emek, "Education, Job Search and Migration." University of Missouri-Columbia Working Paper 02-16. (2003).

Bielby, William T. and Denise D. Bielby, "I Will Follow Him: Family Ties, Gender-Role Beliefs, and Reluctance to Relocate for a Better Job." The American Journal of Sociology, Vol. 97, No. 5, (March 1992), 1241-1267.

Bird, Gerald A. and Gloria W. Bird, "Determinants of Mobility in Two-Earner Families: Does the Wife's Income Count?” Journal of Marriage and Family, Vol. 47, No. 3, (August 1985), 753-758.

Cooke, Thomas and Adrain Bailey, "Family Migration and the Employment of Married Women and Men." Economic Geography, Vol. 72, No.1, (January 1996), 38-48.

Costa, Dora L. and Matthew E. Kahn, "Power Couples: Changes in the Locational Choice of the College Educated, 1940-1990." Quarterly Journal of Economics, Vol. 115, No. 4, (November 2000), 1287-1315.

Drewianka, Scott, "Estimating Social Effects in Matching Markets: Externalities in Spousal Search.” Review of Economics and Statistics, Vol. 85, No. 2, (May 2003), 409-423.

Duncan, R. Paul and Carolyn Cummings Perrucci, "Dual Occupation Families and Migration." American Sociological Review. Vol. 41, No. 2, (April 1976), 252-261.

Ecklof, Jan A. and Sune Karlsson, "Testing and Correcting for Sample Selection Bias in Discrete Choice Contingent Valuation Studies." SSE/EFI Working Paper Series in Economics and Finance, No. 171. Stockholm School of Economics. May 1997, Revised June 1999.

Edlund, Lena, "Sex and the City." The Scandinavian Journal of Economics, Vol. 107, No. 1, (March 2005), 25-44.

Frank, Robert H., "Why Women Earn Less: The Theory and Estimation of Differential Overqualification," American Economic Review, Vol. 68, No. 3 (June 1978), 360-373.

Gardner, Jonathan, Gaelle Pierre and Andrew J. Oswald, "Moving for Job Reasons.” Mimeo. Warwick University. September 2001. (http://www.warwick.ac.uk/fac/soc/

Economics/oswald/GPOeconomica01.pdf).

Glaeser, Edward L., "Learning in MSAs." Journal of Urban Economics, Vol. 46, No. 2, (September 1999), 254-277.

Glaeser, Edward L. and David C. Mare, "Cities and Skills." Journal of Labor Economics, Vol. 19, No.2, (April 2001), 316-342. 
Gould, Eric D. and M. Daniele Paserman, "Waiting for Mr. Right: Rising Inequality and Declining Marriage Rates." Journal of Urban Economics, Vol. 53, No. 2, (March 2003), 257-281.

Green, Anne E., “A Question of Compromise? Case Study Evidence on the Location and Mobility Strategies of Dual Career Households.” Regional Studies, Vol. 31, No. 7,(October 1997), 641-657.

Greenwood, Michael J., "Internal Migration in Developed Countries." in M. R. Rosenzweig and O. Stark (eds.), Handbook of Population and Family Economics. Amsterdam: Elsevier, 1997, 647-720.

Jacobsen, Joyce and Laurence M. Levin, "Marriage and Migration: Comparing Gains and Losses from Migration for Couples and Singles." Social Science Quarterly, Vol.78, No. 3, (September 1997), 688-709.

Jaeger, David A., Susanna Loeb, Sarah E. Turner, and John Bound, "Coding Geographic Areas Across Census Years: Creating Consistent Definitions of Metropolitan Areas." National Bureau of Economic Research, Working Paper No. 6772, (October 1998).

Lundberg, Shelly and Robert A. Pollak, "Efficiency in Marriage." Review of Economics of the Household, Vol. 1, No. 3, (September 2003), 153-168.

Mincer, Jacob, "Family Migration Decisions.” Journal of Political Economy, Vol. 86, No. 5, (October 1978), 749-774.

Morrison, Donna R. and Daniel T. Lichter, "Family Migration and Female Employment: The Problem of Underemployment among Migrant Married Women." Journal of Marriage and Family, Vol. 50, No. 1, (February 1988), 161-172.

Nivalainen, Satu, "Determinants of Family Migration: Short Moves vs. Long Moves." Journal of Population Economics. Vol. 17, No. 1, (February 2004) 157-175.

Polachek, Solomon W. and F.W. Horvath, "A Life Cycle Approach to Migration: Analysis of the Perspicacious Peregrinator.” in R. Ehrenberg (ed.), Research in Labor Economics, Vol. 1. Greenwich CT: JAI Press. 1977, 103-149.

Robst, John and KimMarie McGoldrick, "Gender Differences in Overeducation: A Test of the Theory of Differential Overqualification." The American Economic Review, Vol. 86, No. 2, (May, 1996), 280-284.

Ruggles, Steven and Matthew Sobek, Integrated Public Use Microdata Series, IPUMS-98 Version 2.0. (Social History Research Laboratory. Minneapolis, MN; Department of History, University of Minnesota, 1997), http://www.ipums.umn.edu

Sandell, Steven, H., "Women and the Economics of Family Migration." Review of Economics and Statistics, Vol. 59, No. 4, (November 1977), 406-414. 
Shihadeh, Edward S., "The Prevalence of Husband-Centered Migration: Employment Consequences for Married Mothers." Journal of Marriage and Family, Vol. 53, No. 2, (May 1991), 432-444.

Sjaastad, Larry A., "The Costs and Returns of Human Migration.” Journal of Political Economy, Vol. 70, No. 5, Part 2, (October 1962), 80-93.

Spitze, Glenna D., "The Effect of Family Migration of Wives' Employment: How Long Does it Last?" Social Science Quarterly, Vol. 65, No. 1, (March 1984), 21-36.

University of Michigan. Institute for Social Research (2002). 1969-1993 Panel

Study of Income Dynamics. Retrieved from http://www.isr.umich.edu/src/psid.

U.S. Census Bureau. County and City Data Books (United States), 1988.

U.S. Census Bureau. County and City Data Books (United States), 1993.

van de Ven, Wynand P.M.M. and Bernard M.S. Van Praag, "The Demand for Deductibles in Private Health Insurance.” Journal of Econometrics, Vol. 17, No. 2, (November 1981), 229-252.

Vella, Francis, "Simple Tests for Sample Selection Bias in Censored and Discrete Choice Models." Journal of Applied Econometrics, Vol. 7, No. 4, (October - December 1992), 413-421.

Vella, Francis, "A Simple Estimator for Simultaneous Models with Censored Endogenous Regressors.” International Economic Review, Vol. 34, No. 2, (May 1993), 441-457.

Vella, Francis, "Estimating Models with Sample Selection Bias: A Survey." The Journal of Human Resources, Vol. 33, No. 1, (Winter 1998), 127-169. 


\begin{tabular}{lrrrr}
\hline & \multicolumn{1}{c}{1970} & 1980 & \multicolumn{1}{c}{1990} & \multicolumn{1}{c}{2000} \\
\hline New York-Northern New Jersey-Long Island, NY-NJ-CT-PA & $18,071,522$ & $17,412,203$ & $17,953,372$ & $19,451,757$ \\
Los Angeles-Anaheim-Riverside, CA & $9,980,859$ & $11,497,549$ & $14,531,529$ & $16,036,587$ \\
Chicago-Gary-Lake County, IL-IN-WI & $7,778,948$ & $7,937,290$ & $8,065,633$ & $8,783,199$ \\
San Francisco-Oakland-San Jose, CA & $4,754,366$ & $5,367,900$ & $6,253,311$ & $6,873,645$ \\
Philadelphia-Wilmington-Trenton, PA-NJ-DE-MD & $5,749,093$ & $5,680,509$ & $5,899,345$ & $5,661,399$ \\
Detroit-Ann Arbor, MI & $4,788,369$ & $4,752,764$ & $4,665,236$ & $5,031,963$ \\
Washington, DC-MD-VA-WV & $3,040,307$ & $3,250,921$ & $3,923,574$ & $4,739,999$ \\
Dallas-Fort Worth, TX & $2,351,568$ & $2,930,568$ & $3,885,415$ & $4,909,523$ \\
Boston-Lawrence-Salem-Lowell-Brocton, MA-NH-ME-CT & $3,709,642$ & $3,662,888$ & $3,783,817$ & $4,440,881$ \\
Houston-Galveston-Brazoria, TX & $2,169,128$ & $3,099,942$ & $3,711,043$ & $4,493,741$ \\
Miami-Fort Lauderdale, FL & $1,887,892$ & $2,643,766$ & $3,192,582$ & $3,711,102$ \\
Atlanta, GA & $1,684,200$ & $2,138,136$ & $2,833,511$ & $3,857,097$ \\
Cleveland-Akron-Lorain, OH & $2,999,811$ & $2,834,062$ & $2,759,823$ & $2,910,616$ \\
Seattle-Tacoma, WA & $1,836,949$ & $2,093,285$ & $2,559,164$ & $3,023,741$ \\
San Diego, CA & $1,357,854$ & $1,861,846$ & $2,498,016$ & $2,820,844$ \\
Minneapolis-St. Paul, MN-WI & $1,981,951$ & $2,137,133$ & $2,464,124$ & $2,872,109$ \\
St. Louis, MO-IL & $2,429,376$ & $2,376,968$ & $2,444,099$ & $2,569,029$ \\
Baltimore, MD & $2,089,438$ & $2,199,497$ & $2,382,172$ & $2,491,254$ \\
Pittsburgh-Beaver Valley, PA & $2,556,029$ & $2,423,311$ & $2,242,798$ & $2,331,336$ \\
Phoenix, AZ & 971,228 & $1,509,175$ & $2,122,101$ & $3,013,696$ \\
Tampa-St. Petersburg-Clearwater, FL & $1,105,553$ & $1,613,600$ & $2,067,959$ & $2,278,169$ \\
Denver-Boulder, CO & $1,238,273$ & $1,618,461$ & $1,848,319$ & $2,252,103$
\end{tabular}

MSAs are defined as 'large' if their population is greater than 2M in 1990. The analyses here uses the MSA definitions, i.e., county components, from the 1990 definitions. 


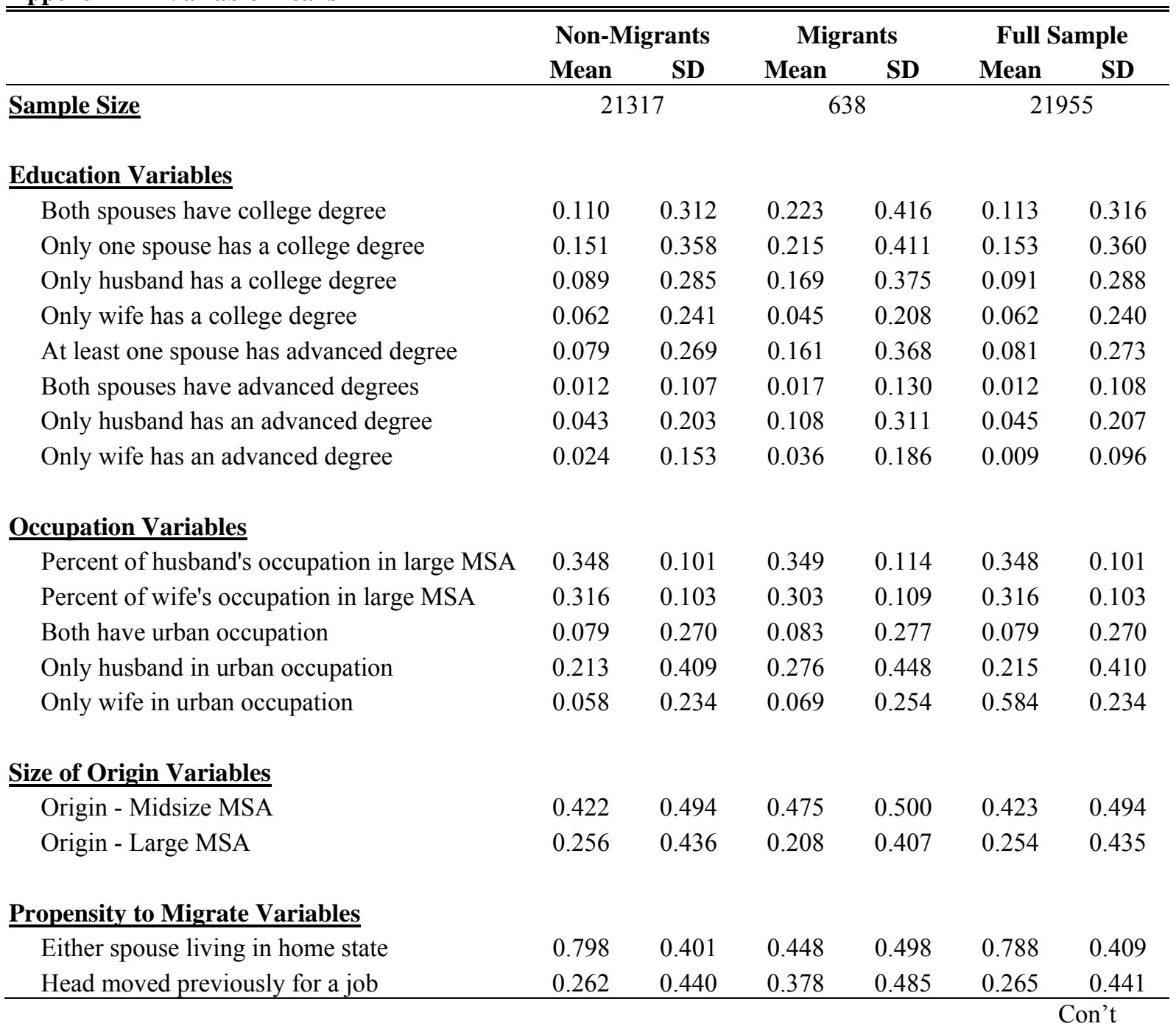




\begin{tabular}{lcccccc}
\hline & \multicolumn{2}{c}{ Non-Migrants } & \multicolumn{2}{c}{ Migrants } & \multicolumn{2}{c}{ Full Sample } \\
& Mean & SD & Mean & SD & Mean & SD \\
\hline Labor Force Attachment & & & & & & \\
\hline Number of months duration, husband's job & 60.31 & 59.47 & 49.03 & 54.56 & 59.98 & 59.36 \\
Number of months duration, wife's job & 31.05 & 44.89 & 15.68 & 27.73 & 30.60 & 44.56 \\
Husband unemployed & 0.044 & 0.205 & 0.050 & 0.218 & 0.044 & 0.205 \\
Wife unemployed & 0.029 & 0.169 & 0.042 & 0.201 & 0.030 & 0.170 \\
Husband not in the labor force & 0.021 & 0.145 & 0.044 & 0.205 & 0.022 & 0.147 \\
Wife not in the labor force & 0.332 & 0.471 & 0.408 & 0.492 & 0.338 & 0.472 \\
Total family income & 44200 & 29206 & 44706 & 27866 & 44214 & 29167 \\
Basic Demographics & & & & & & \\
$\quad$ Husband aged 25-29 & 0.307 & 0.461 & 0.422 & 0.494 & 0.310 & 0.463 \\
Husband aged 30-34 & 0.398 & 0.489 & 0.364 & 0.481 & 0.397 & 0.489 \\
$\quad$ Wife aged 23-27 & 0.302 & 0.459 & 0.386 & 0.487 & 0.304 & 0.460 \\
Wife aged 28-32 & 0.407 & 0.491 & 0.384 & 0.487 & 0.406 & 0.491 \\
Child aged 0-5 present in household & 0.563 & 0.496 & 0.539 & 0.499 & 0.562 & 0.496 \\
School aged child present in household & 0.310 & 0.462 & 0.343 & 0.475 & 0.311 & 0.463 \\
Home owner & 0.656 & 0.475 & 0.455 & 0.498 & 0.650 & 0.477 \\
Either spouse non-white & 0.295 & 0.456 & 0.218 & 0.413 & 0.292 & 0.455 \\
& & & & & & \\
Origin MSA Attributes & & & & & & \\
$\quad$ Average growth rate of origin MSA & -0.076 & 0.124 & -0.109 & 0.126 & -0.077 & 0.124 \\
Average housing value in origin MSA & 108.74 & 74.57 & 120.37 & 82.27 & 109.09 & 74.83 \\
Distance to nearest MSA greater than 2M & 148.43 & 170.40 & 207.28 & 343.28 & 150.14 & 178.07 \\
\hline \hline
\end{tabular}


Appendix C(i) - Effect of Power Status on Probability of Migrating: Testing Sample Selection.

Full Regression Results (Table 1)

\begin{tabular}{|c|c|c|c|c|c|c|}
\hline & $\begin{array}{l}\text { Probit: } \\
\text { Without } \\
\text { Sample } \\
\text { Selection } \\
\text { Controls }\end{array}$ & Test & $\begin{array}{l}\text { Probit: } \\
\text { r Sample }\end{array}$ & ction & $\begin{array}{l}\text { Maximum } \\
\text { Likelihood } \\
\text { Estimation }\end{array}$ & $\begin{array}{c}\text { ML } \\
\text { Estimation } \\
\text { without Past } \\
\text { Behavior } \\
\text { Variables }\end{array}$ \\
\hline & (A) & (B) & (C) & (D) & (E) & (F) \\
\hline $\begin{array}{l}\text { Power: Both spouses have college } \\
\text { degrees }\end{array}$ & $\begin{array}{c}0.378 \\
(0.060)\end{array}$ & $\begin{array}{c}0.363 \\
(0.085)\end{array}$ & $\begin{array}{c}0.396 \\
(0.076)\end{array}$ & $\begin{array}{c}0.346 \\
(0.084)\end{array}$ & $\begin{array}{c}0.383 \\
(0.059)\end{array}$ & $\begin{array}{c}0.199 \\
(0.177)\end{array}$ \\
\hline $\begin{array}{l}\text { Half Power: Only one spouse has a } \\
\text { college degree }\end{array}$ & $\begin{array}{c}0.245 \\
(0.000)\end{array}$ & $\begin{array}{c}0.249 \\
(0.080)\end{array}$ & $\begin{array}{c}0.266 \\
(0.078)\end{array}$ & $\begin{array}{c}0.218 \\
(0.073)\end{array}$ & $\begin{array}{c}0.254 \\
(0.053)\end{array}$ & $\begin{array}{c}0.095 \\
(0.122)\end{array}$ \\
\hline Origin: Midsize MSA & $\begin{array}{l}-0.018 \\
(0.045)\end{array}$ & $\begin{array}{l}-0.016 \\
(0.044)\end{array}$ & $\begin{array}{l}-0.018 \\
(0.045)\end{array}$ & $\begin{array}{l}-0.017 \\
(0.045)\end{array}$ & $\begin{array}{l}-0.019 \\
(0.044)\end{array}$ & $\begin{array}{l}-0.020 \\
(0.030)\end{array}$ \\
\hline Origin: Large MSA & $\begin{array}{l}-0.165 \\
(0.065)\end{array}$ & $\begin{array}{l}-0.162 \\
(0.066)\end{array}$ & $\begin{array}{l}-0.165 \\
(0.065)\end{array}$ & $\begin{array}{l}-0.163 \\
(0.065)\end{array}$ & $\begin{array}{l}-0.163 \\
(0.064)\end{array}$ & $\begin{array}{l}-0.094 \\
(0.058)\end{array}$ \\
\hline $\begin{array}{l}\text { Currently residing in home state of at } \\
\text { least one spouse }\end{array}$ & $\begin{array}{l}-0.543 \\
(0.040)\end{array}$ & $\begin{array}{l}-0.542 \\
(0.040)\end{array}$ & $\begin{array}{l}-0.543 \\
(0.040)\end{array}$ & $\begin{array}{l}-0.543 \\
(0.040)\end{array}$ & $\begin{array}{l}-0.531 \\
(0.043)\end{array}$ & \\
\hline Head has previously moved for a job & $\begin{array}{c}0.092 \\
(0.044)\end{array}$ & $\begin{array}{c}0.094 \\
(0.044)\end{array}$ & $\begin{array}{c}0.093 \\
(0.044)\end{array}$ & $\begin{array}{c}0.092 \\
(0.045)\end{array}$ & $\begin{array}{c}0.090 \\
(0.044)\end{array}$ & \\
\hline MSA growth rate & $\begin{array}{l}-0.371 \\
(0.159)\end{array}$ & $\begin{array}{l}-0.371 \\
(0.159)\end{array}$ & $\begin{array}{l}-0.372 \\
(0.159)\end{array}$ & $\begin{array}{l}-0.370 \\
(0.159)\end{array}$ & $\begin{array}{l}-0.364 \\
(0.155)\end{array}$ & $\begin{array}{l}-0.570 \\
(0.211)\end{array}$ \\
\hline House value & $\begin{array}{c}0.0003 \\
(0.0003)\end{array}$ & $\begin{array}{c}0.0003 \\
(0.0003)\end{array}$ & $\begin{array}{c}0.0003 \\
(0.0003)\end{array}$ & $\begin{array}{c}0.0003 \\
(0.0003)\end{array}$ & $\begin{array}{c}0.0003 \\
(0.0003)\end{array}$ & $\begin{array}{c}0.0002 \\
(0.0002)\end{array}$ \\
\hline Distance to closest large MSA & $\begin{array}{l}0.0003 \\
(0.000)\end{array}$ & $\begin{array}{l}0.0003 \\
(0.000)\end{array}$ & $\begin{array}{l}0.0003 \\
(0.000)\end{array}$ & $\begin{array}{l}0.0003 \\
(0.000)\end{array}$ & $\begin{array}{l}0.0003 \\
(0.000)\end{array}$ & $\begin{array}{l}0.0003 \\
(0.000)\end{array}$ \\
\hline Husband aged 25-29 & $\begin{array}{c}0.192 \\
(0.068)\end{array}$ & $\begin{array}{c}0.202 \\
(0.068)\end{array}$ & $\begin{array}{c}0.191 \\
(0.068)\end{array}$ & $\begin{array}{c}0.199 \\
(0.068)\end{array}$ & $\begin{array}{c}0.187 \\
(0.068)\end{array}$ & $\begin{array}{c}0.145 \\
(0.062)\end{array}$ \\
\hline Husband aged 30-34 & $\begin{array}{c}0.058 \\
(0.053)\end{array}$ & $\begin{array}{c}0.046 \\
(0.056)\end{array}$ & $\begin{array}{c}0.051 \\
(0.057)\end{array}$ & $\begin{array}{c}0.064 \\
(0.053)\end{array}$ & $\begin{array}{c}0.051 \\
(0.052)\end{array}$ & $\begin{array}{c}0.068 \\
(0.040)\end{array}$ \\
\hline Wife aged 23-27 & $\begin{array}{c}0.068 \\
(0.068)\end{array}$ & $\begin{array}{c}0.108 \\
(0.085)\end{array}$ & $\begin{array}{c}0.059 \\
(0.072)\end{array}$ & $\begin{array}{c}0.095 \\
(0.084)\end{array}$ & $\begin{array}{c}0.059 \\
(0.067)\end{array}$ & $\begin{array}{c}0.108 \\
(0.064)\end{array}$ \\
\hline Wife aged $28-32$ & $\begin{array}{c}0.023 \\
(0.055)\end{array}$ & $\begin{array}{c}0.031 \\
(0.057)\end{array}$ & $\begin{array}{c}0.021 \\
(0.055)\end{array}$ & $\begin{array}{c}0.029 \\
(0.056)\end{array}$ & $\begin{array}{c}0.021 \\
(0.054)\end{array}$ & $\begin{array}{c}0.033 \\
(0.044)\end{array}$ \\
\hline Child aged $0-5$ present in household & $\begin{array}{l}-0.109 \\
(0.049)\end{array}$ & $\begin{array}{l}-0.102 \\
(0.226)\end{array}$ & $\begin{array}{l}-0.040 \\
(0.053)\end{array}$ & $\begin{array}{l}-0.119 \\
(0.051)\end{array}$ & $\begin{array}{l}-0.050 \\
(0.056)\end{array}$ & $\begin{array}{l}-\mathbf{0 . 1 1 8} \\
(\mathbf{0 . 0 3 6 )}\end{array}$ \\
\hline $\begin{array}{l}\text { School aged child present in } \\
\text { household }\end{array}$ & $\begin{array}{c}0.039 \\
(0.048)\end{array}$ & $\begin{array}{c}0.043 \\
(0.052)\end{array}$ & $\begin{array}{c}0.047 \\
(0.053)\end{array}$ & $\begin{array}{c}0.030 \\
(0.050)\end{array}$ & $\begin{array}{c}0.045 \\
(0.047)\end{array}$ & $\begin{array}{c}0.011 \\
(0.041)\end{array}$ \\
\hline Home owner & $\begin{array}{l}-0.291 \\
(0.041)\end{array}$ & $\begin{array}{l}-0.269 \\
(0.097)\end{array}$ & $\begin{array}{l}-0.256 \\
(0.102)\end{array}$ & $\begin{array}{l}-0.329 \\
(0.076)\end{array}$ & $\begin{array}{l}-0.257 \\
(0.044)\end{array}$ & $\begin{array}{l}-0.431 \\
(0.035)\end{array}$ \\
\hline $\begin{array}{l}\text { Number of months duration, } \\
\text { husband's job }\end{array}$ & $\begin{array}{c}0.0002 \\
(0.0004)\end{array}$ & $\begin{array}{c}0.0002 \\
(0.0004)\end{array}$ & $\begin{array}{c}0.0002 \\
(0.0004)\end{array}$ & $\begin{array}{c}0.0002 \\
(0.0004)\end{array}$ & $\begin{array}{c}0.0002 \\
(0.0004)\end{array}$ & $\begin{array}{c}0.0000 \\
(0.0003)\end{array}$ \\
\hline $\begin{array}{l}\text { Number of months duration, wife's } \\
\text { job }\end{array}$ & $\begin{array}{l}-0.003 \\
(0.001)\end{array}$ & $\begin{array}{l}-0.003 \\
(0.001)\end{array}$ & $\begin{array}{l}-0.003 \\
(0.001)\end{array}$ & $\begin{array}{l}-0.003 \\
(0.001)\end{array}$ & $\begin{array}{l}-0.003 \\
(0.001)\end{array}$ & $\begin{array}{l}-0.003 \\
(0.001)\end{array}$ \\
\hline Husband unemployed & $\begin{array}{c}0.109 \\
(0.096)\end{array}$ & $\begin{array}{c}0.101 \\
(0.124)\end{array}$ & $\begin{array}{c}0.079 \\
(0.121)\end{array}$ & $\begin{array}{c}0.147 \\
(0.116)\end{array}$ & $\begin{array}{c}0.082 \\
(0.095)\end{array}$ & $\begin{array}{c}0.189 \\
(0.073)\end{array}$ \\
\hline Wife unemployed & $\begin{array}{c}0.036 \\
(0.102)\end{array}$ & $\begin{array}{c}0.002 \\
(0.132)\end{array}$ & $\begin{array}{c}0.006 \\
(0.134)\end{array}$ & $\begin{array}{c}0.065 \\
(0.117)\end{array}$ & $\begin{array}{c}0.007 \\
(0.102)\end{array}$ & $\begin{array}{c}0.110 \\
(0.072)\end{array}$ \\
\hline
\end{tabular}




\begin{tabular}{|c|c|c|c|c|c|c|}
\hline & $\begin{array}{l}\text { Probit: } \\
\text { Without } \\
\text { Sample } \\
\text { Selection } \\
\text { Controls }\end{array}$ & Tests & $\begin{array}{l}\text { Probit: } \\
\text { r Sample S }\end{array}$ & ection & $\begin{array}{l}\text { Maximum } \\
\text { Likelihood } \\
\text { Estimation }\end{array}$ & $\begin{array}{c}\text { ML } \\
\text { Estimation } \\
\text { without Past } \\
\text { Behavior } \\
\text { Variables }\end{array}$ \\
\hline & (A) & (B) & (C) & (D) & (E) & $(\mathrm{F})$ \\
\hline Husband not in the labor force & $\begin{array}{c}0.280 \\
(0.097)\end{array}$ & $\begin{array}{c}0.257 \\
(0.128)\end{array}$ & $\begin{array}{c}0.251 \\
(0.125)\end{array}$ & $\begin{array}{c}0.314 \\
(0.115)\end{array}$ & $\begin{array}{c}0.247 \\
(0.099)\end{array}$ & $\begin{array}{c}0.299 \\
(0.079)\end{array}$ \\
\hline Wife not in the labor force & $\begin{array}{c}0.051 \\
(0.048)\end{array}$ & $\begin{array}{c}0.010 \\
(0.072)\end{array}$ & $\begin{array}{c}0.044 \\
(0.050)\end{array}$ & $\begin{array}{c}0.035 \\
(0.058)\end{array}$ & $\begin{array}{c}0.045 \\
(0.047)\end{array}$ & $\begin{array}{l}-0.004 \\
(0.044)\end{array}$ \\
\hline Either of spouses non-white & $\begin{array}{l}-0.125 \\
(0.050)\end{array}$ & $\begin{array}{l}-0.105 \\
(0.062)\end{array}$ & $\begin{array}{l}-0.133 \\
(0.056)\end{array}$ & $\begin{array}{l}-0.104 \\
(0.061)\end{array}$ & $\begin{array}{l}-0.129 \\
(0.049)\end{array}$ & $\begin{array}{l}-0.027 \\
(0.072)\end{array}$ \\
\hline Total family income & $\begin{array}{l}9.11 \mathrm{E}-08 \\
(6.0 \mathrm{E}-07)\end{array}$ & $\begin{array}{l}1.11 \mathrm{E}-07 \\
(6.0 \mathrm{E}-07)\end{array}$ & $\begin{array}{c}8.7 \mathrm{E}-08 \\
(6.0 \mathrm{E}-07)\end{array}$ & $\begin{array}{c}1.2 \mathrm{E}-07 \\
(6.0 \mathrm{E}-07)\end{array}$ & $\begin{array}{c}9.4 \mathrm{E}-08 \\
(5.9 \mathrm{E}-07)\end{array}$ & $\begin{array}{c}5.5 \mathrm{E}-07 \\
(4.6 \mathrm{E}-07)\end{array}$ \\
\hline Constant & $\begin{array}{l}-1.581 \\
(0.092)\end{array}$ & $\begin{array}{l}-1.839 \\
(0.400)\end{array}$ & $\begin{array}{l}-1.729 \\
(0.419)\end{array}$ & $\begin{array}{l}-1.486 \\
(0.191)\end{array}$ & $\begin{array}{l}-1.693 \\
(0.096)\end{array}$ & $\begin{array}{l}-1.348 \\
(0.244)\end{array}$ \\
\hline$\lambda_{1}$ & & $\begin{array}{l}-0.511 \\
(1.129)\end{array}$ & & $\begin{array}{l}-0.645 \\
(1.114)\end{array}$ & & \\
\hline$\lambda_{2}$ & & $\begin{array}{c}1.157 \\
(1.163)\end{array}$ & $\begin{array}{c}0.389 \\
(1.086)\end{array}$ & & & \\
\hline$\rho$ & & & & & $\begin{array}{c}0.478 \\
(0.511) \\
\end{array}$ & $\begin{array}{l}-0.891 \\
(0.152) \\
\end{array}$ \\
\hline Number of Observations & 21955 & 21955 & 21955 & 21955 & 21955 & 21955 \\
\hline Wald Chi2 & 588.41 & 590.54 & 587.3 & 592.07 & 438.39 & 425.23 \\
\hline Prof $>$ chi2 & 0.000 & 0.000 & 0.000 & 0.000 & 0.000 & 0.000 \\
\hline Pseudo R2 & 0.111 & 0.111 & 0.111 & 0.111 & & \\
\hline Log pseudolikelihood & & & & & -12439.5 & -9383.87 \\
\hline $\begin{array}{l}\text { Wald test of independent equations } \\
(\rho=0) \\
\text { Test Statistic: } \chi^{2}(1) \\
\text { Prob }>\chi^{2}\end{array}$ & & & & & $\begin{array}{c}0.62 \\
0.432\end{array}$ & $\begin{array}{c}3.76 \\
0.052\end{array}$ \\
\hline
\end{tabular}

Coefficients and standard errors presented. Standard errors are adjusted for clustering on household identifier.

Bold coefficients are significant at the $95 \%$ confidence level or higher. 


\begin{tabular}{|c|c|c|c|c|c|}
\hline Selection equation & $\begin{array}{l}\text { Probit: } \\
\text { Non- } \\
\text { attrition }\end{array}$ & $\begin{array}{c}\text { Probit: } \\
\text { No Divorce }\end{array}$ & $\begin{array}{c}\text { Probit: } \\
\text { No Divorce } \\
\text { and No } \\
\text { Attrition } \\
\end{array}$ & $\begin{array}{c}\text { ML: } \\
\text { No Divorce } \\
\text { and No } \\
\text { Attrition } \\
\end{array}$ & $\begin{array}{c}\text { ML: } \\
\text { No Divorce } \\
\text { and No } \\
\text { Attrition } \\
\end{array}$ \\
\hline Reference column in table 1 & (B) & (B), (D) & $(\mathrm{C})$ & $(\mathrm{E})$ & $(\mathbf{F})$ \\
\hline Power: Both spouses have college degrees & $\begin{array}{c}0.038 \\
(0.051)\end{array}$ & $\begin{array}{c}0.302 \\
(0.056)\end{array}$ & $\begin{array}{c}0.155 \\
(0.042)\end{array}$ & $\begin{array}{c}0.138 \\
(0.034)\end{array}$ & $\begin{array}{c}0.292 \\
(0.046)\end{array}$ \\
\hline Half Power: Only one spouse has a college degree & $\begin{array}{c}0.912 \\
(0.037)\end{array}$ & $\begin{array}{c}0.224 \\
(0.044)\end{array}$ & $\begin{array}{c}0.167 \\
(0.031)\end{array}$ & $\begin{array}{c}0.152 \\
(0.029)\end{array}$ & $\begin{array}{c}0.211 \\
(0.036)\end{array}$ \\
\hline Child aged 0-5 present in household & $\begin{array}{c}0.743 \\
(0.330)\end{array}$ & $\begin{array}{c}0.094 \\
(0.033)\end{array}$ & $\begin{array}{c}0.521 \\
(0.027)\end{array}$ & $\begin{array}{c}0.523 \\
(0.023)\end{array}$ & $\begin{array}{c}0.097 \\
(\mathbf{0 . 0 2 6})\end{array}$ \\
\hline School aged child present in household & $\begin{array}{c}0.072 \\
(0.038)\end{array}$ & $\begin{array}{c}0.068 \\
(0.036)\end{array}$ & $\begin{array}{c}0.082 \\
(0.030)\end{array}$ & $\begin{array}{c}0.083 \\
(0.025)\end{array}$ & $\begin{array}{c}0.035 \\
(0.028)\end{array}$ \\
\hline Disabled & $\begin{array}{c}0.080 \\
(0.037)\end{array}$ & $\begin{array}{l}-0.137 \\
(0.040)\end{array}$ & $\begin{array}{l}-0.019 \\
(0.031)\end{array}$ & $\begin{array}{l}-0.020 \\
(0.027)\end{array}$ & $\begin{array}{l}-0.084 \\
(0.036)\end{array}$ \\
\hline Wife aged 23-27 & $\begin{array}{c}0.054 \\
(0.048)\end{array}$ & $\begin{array}{l}-0.227 \\
(0.047)\end{array}$ & $\begin{array}{l}-0.078 \\
(0.038)\end{array}$ & $\begin{array}{l}-0.076 \\
(0.031)\end{array}$ & $\begin{array}{l}-0.178 \\
(0.038)\end{array}$ \\
\hline Wife aged $28-32$ & $\begin{array}{c}0.013 \\
(0.034)\end{array}$ & $\begin{array}{l}-0.068 \\
(0.041)\end{array}$ & $\begin{array}{l}-0.014 \\
(0.029)\end{array}$ & $\begin{array}{l}-0.011 \\
(0.021)\end{array}$ & $\begin{array}{l}-0.066 \\
(0.031)\end{array}$ \\
\hline Husband aged 25-29 & $\begin{array}{c}0.213 \\
(0.462)\end{array}$ & $\begin{array}{l}-0.068 \\
(0.048)\end{array}$ & $\begin{array}{l}-0.017 \\
(0.037)\end{array}$ & $\begin{array}{l}-0.003 \\
(0.031)\end{array}$ & $\begin{array}{l}-0.059 \\
(0.037)\end{array}$ \\
\hline Husband aged 30-34 & $\begin{array}{l}-0.055 \\
(0.033)\end{array}$ & $\begin{array}{l}-0.056 \\
(0.041)\end{array}$ & $\begin{array}{c}-0.058 \\
(0.029)\end{array}$ & $\begin{array}{l}-0.053 \\
(0.022)\end{array}$ & $\begin{array}{l}-0.061 \\
(0.031)\end{array}$ \\
\hline Husband not in the labor force & $\begin{array}{c}-0.182 \\
(0.074)\end{array}$ & $\begin{array}{l}-0.175 \\
(\mathbf{0 . 0 8 3 )}\end{array}$ & $\begin{array}{l}-0.197 \\
(0.064)\end{array}$ & $\begin{array}{c}0.191 \\
(0.056)\end{array}$ & $\begin{array}{l}-0.189 \\
(0.069)\end{array}$ \\
\hline Husband unemployed & $\begin{array}{c}-0.132 \\
(0.053)\end{array}$ & $\begin{array}{c}-0.212 \\
(0.056)\end{array}$ & $\begin{array}{l}-0.197 \\
(0.064)\end{array}$ & $\begin{array}{c}0.197 \\
(0.038)\end{array}$ & $\begin{array}{l}-0.224 \\
(0.045)\end{array}$ \\
\hline Wife not in the labor force & $\begin{array}{l}-0.175 \\
(0.285)\end{array}$ & $\begin{array}{c}0.142 \\
(0.032)\end{array}$ & $\begin{array}{l}-0.050 \\
(0.024)\end{array}$ & $\begin{array}{c}0.050 \\
(0.020)\end{array}$ & $\begin{array}{c}0.078 \\
(0.025)\end{array}$ \\
\hline Wife unemployed & $\begin{array}{l}-0.183 \\
(0.061)\end{array}$ & $\begin{array}{l}-0.153 \\
(0.069)\end{array}$ & $\begin{array}{l}-0.196 \\
(0.053)\end{array}$ & $\begin{array}{l}-0.196 \\
(0.044)\end{array}$ & $\begin{array}{c}-0.141 \\
(0.056)\end{array}$ \\
\hline Home owner & $\begin{array}{c}0.187 \\
(0.029)\end{array}$ & $\begin{array}{c}0.304 \\
(0.030)\end{array}$ & $\begin{array}{c}0.270 \\
(0.024)\end{array}$ & $\begin{array}{c}0.273 \\
(0.021)\end{array}$ & $\begin{array}{c}0.327 \\
(0.025)\end{array}$ \\
\hline Either of spouses non-white & $\begin{array}{c}0.021 \\
(0.031)\end{array}$ & $\begin{array}{l}-0.139 \\
(0.031)\end{array}$ & $\begin{array}{l}-\mathbf{0 . 0 6 4} \\
(\mathbf{0 . 0 2 6 )}\end{array}$ & $\begin{array}{l}-\mathbf{0 . 0 7 1} \\
(\mathbf{0 . 0 2 4 )}\end{array}$ & $\begin{array}{l}-0.119 \\
(0.026)\end{array}$ \\
\hline Constant & $\begin{array}{c}0.976 \\
(0.038)\end{array}$ & $\begin{array}{c}1.497 \\
(0.043)\end{array}$ & $\begin{array}{c}0.757 \\
(\mathbf{0 . 0 3 2})\end{array}$ & $\begin{array}{c}0.734 \\
(\mathbf{0 . 0 2 8})\end{array}$ & $\begin{array}{c}1.255 \\
(0.034)\end{array}$ \\
\hline Number of Observations & 26324 & 24060 & 26324 & 25573 & 24009 \\
\hline Wald Chi2 & 766.44 & 485.58 & 857.71 & 438.39 & 425.23 \\
\hline Prof $>$ chi2 & 0.000 & 0.000 & 0.000 & 0.000 & 0.000 \\
\hline Pseudo R2 & 0.076 & 0.049 & 0.053 & & \\
\hline
\end{tabular}

Coefficients and standard errors presented. Standard errors are adjusted for clustering on household identifier.

Bold coefficients are significant at the $95 \%$ confidence level or higher. Sample size for columns E and F are less than the full sample due to observations dropped for missing values in main equation. 
Appendix D - Full Regression Results for preferred specifications.

\begin{tabular}{|c|c|c|c|c|c|}
\hline & \multicolumn{2}{|c|}{ Table 2 (col. B) } & \multicolumn{3}{|c|}{ Table 3a (Col. B) } \\
\hline & $\begin{array}{c}\text { Probability } \\
\text { of Migration }\end{array}$ & $\begin{array}{l}\text { Selection } \\
\text { Equation }\end{array}$ & Small & Med & Large \\
\hline Power: Both spouses have college degree & $\begin{array}{c}0.385 \\
(0.058)\end{array}$ & $\begin{array}{c}0.138 \\
(0.034)\end{array}$ & $\begin{array}{c}0.617 \\
(0.226)\end{array}$ & $\begin{array}{c}0.956 \\
(0.171)\end{array}$ & $\begin{array}{c}1.048 \\
(0.272)\end{array}$ \\
\hline $\begin{array}{l}\text { Husband Power: Only husband has college } \\
\text { degree }\end{array}$ & $\begin{array}{c}0.358 \\
(0.061)\end{array}$ & $\begin{array}{c}0.207 \\
(0.036)\end{array}$ & $\begin{array}{c}0.340 \\
(0.226)\end{array}$ & $\begin{array}{c}0.560 \\
(0.206)\end{array}$ & $\begin{array}{c}1.624 \\
(0.226)\end{array}$ \\
\hline Wife Power: Only wife has college degree & $\begin{array}{c}0.025 \\
(0.090)\end{array}$ & $\begin{array}{c}0.078 \\
(0.044)\end{array}$ & $\begin{array}{l}-0.267 \\
(0.389)\end{array}$ & $\begin{array}{c}0.252 \\
(0.275)\end{array}$ & $\begin{array}{c}0.016 \\
(0.471)\end{array}$ \\
\hline Origin - Midsize MSA & $\begin{array}{l}-0.018 \\
(0.044)\end{array}$ & & $\begin{array}{l}-0.396 \\
(0.181)\end{array}$ & $\begin{array}{c}0.039 \\
(0.148)\end{array}$ & $\begin{array}{c}0.473 \\
(0.244)\end{array}$ \\
\hline Origin - Large MSA & $\begin{array}{c}-0158 \\
(0.064)\end{array}$ & & $\begin{array}{l}-0.751 \\
(0.255)\end{array}$ & $\begin{array}{l}-0.257 \\
(0.213)\end{array}$ & $\begin{array}{c}0.119 \\
(0.331)\end{array}$ \\
\hline $\begin{array}{c}\text { Currently residing in home state of at least } \\
\text { one spouse }\end{array}$ & $\begin{array}{l}-0.525 \\
(0.041)\end{array}$ & & $\begin{array}{l}-1.308 \\
(0.161)\end{array}$ & $\begin{array}{l}-1.208 \\
(0.133)\end{array}$ & $\begin{array}{l}-1.116 \\
(0.200)\end{array}$ \\
\hline Head has previously moved for a job & $\begin{array}{c}0.088 \\
(0.044)\end{array}$ & & $\begin{array}{c}0.451 \\
(0.159)\end{array}$ & $\begin{array}{l}-0.031 \\
(0.138)\end{array}$ & $\begin{array}{c}0.156 \\
(0.206)\end{array}$ \\
\hline MSA growth rate & $\begin{array}{c}-0358 \\
(0.155)\end{array}$ & & $\begin{array}{c}0.007 \\
(0.602)\end{array}$ & $\begin{array}{l}-1.581 \\
(0.512)\end{array}$ & $\begin{array}{l}-0.118 \\
(0.765)\end{array}$ \\
\hline House value & $\begin{array}{c}0.0003 \\
(0.0003)\end{array}$ & & $\begin{array}{l}-0.001 \\
(0.001)\end{array}$ & $\begin{array}{c}0.001 \\
(0.000)\end{array}$ & $\begin{array}{r}-0.0002 \\
(0.001)\end{array}$ \\
\hline Distance to closest large MSA & $\begin{array}{c}0.0003 \\
(0.0000)\end{array}$ & & $\begin{array}{c}0.001 \\
(0.000)\end{array}$ & $\begin{array}{c}0.001 \\
(0.000)\end{array}$ & $\begin{array}{c}0.001 \\
(0.000)\end{array}$ \\
\hline Husband aged 25-29 & $\begin{array}{c}0.198 \\
(0.067)\end{array}$ & $\begin{array}{c}0.001 \\
(0.031)\end{array}$ & $\begin{array}{c}0.759 \\
(0.246)\end{array}$ & $\begin{array}{c}0.176 \\
(0.208)\end{array}$ & $\begin{array}{c}0.696 \\
(0.366)\end{array}$ \\
\hline Husband aged 30-34 & $\begin{array}{c}0.055 \\
(0.052)\end{array}$ & $\begin{array}{c}-0.051 \\
(0.022)\end{array}$ & $\begin{array}{c}0.174 \\
(0.219)\end{array}$ & $\begin{array}{c}0.099 \\
(0.158)\end{array}$ & $\begin{array}{c}0.230 \\
(0.297)\end{array}$ \\
\hline Wife aged $23-27$ & $\begin{array}{c}0.055 \\
(0.066)\end{array}$ & $\begin{array}{c}-0.078 \\
(0.031)\end{array}$ & $\begin{array}{l}-0.279 \\
(0.249)\end{array}$ & $\begin{array}{c}0.447 \\
(0.208)\end{array}$ & $\begin{array}{c}0.115 \\
(0.354)\end{array}$ \\
\hline Wife aged $28-32$ & $\begin{array}{c}0.018 \\
(0.054)\end{array}$ & $\begin{array}{c}-0.012 \\
(0.021)\end{array}$ & $\begin{array}{l}-0.138 \\
(0.217)\end{array}$ & $\begin{array}{c}0.203 \\
(0.168)\end{array}$ & $\begin{array}{c}-0.049 \\
(0.284)\end{array}$ \\
\hline Child aged $0-5$ present in household & $\begin{array}{c}-0.046 \\
(0.050)\end{array}$ & $\begin{array}{c}0.523 \\
(0.023)\end{array}$ & $\begin{array}{c}-0.477 \\
(0.186)\end{array}$ & $\begin{array}{l}-0.186 \\
(0.156)\end{array}$ & $\begin{array}{c}0.098 \\
(0.244)\end{array}$ \\
\hline School aged child present in household & $\begin{array}{c}0.048 \\
(0.047)\end{array}$ & $\begin{array}{c}0.083 \\
(0.025)\end{array}$ & $\begin{array}{c}0.311 \\
(0.187)\end{array}$ & $\begin{array}{l}-0.017 \\
(0.153)\end{array}$ & $\begin{array}{l}-0.081 \\
(0.258)\end{array}$ \\
\hline Home owner & $\begin{array}{c}-0.254 \\
(0.041)\end{array}$ & $\begin{array}{c}0.274 \\
(0.021)\end{array}$ & $\begin{array}{c}-0.549 \\
(0.169)\end{array}$ & $\begin{array}{c}-0.759 \\
(0.133)\end{array}$ & $\begin{array}{c}-0.547 \\
(0.191)\end{array}$ \\
\hline Number of months duration, husband's job & $\begin{array}{c}0.0001 \\
(0.0004)\end{array}$ & & $\begin{array}{l}-0.001 \\
(0.002)\end{array}$ & $\begin{array}{c}0.002 \\
(0001)\end{array}$ & $\begin{array}{c}-0.002 \\
(0.002)\end{array}$ \\
\hline Number of months duration, wife's job & $\begin{array}{c}-0.003 \\
(0.001)\end{array}$ & & $\begin{array}{c}-0.014 \\
(0.004)\end{array}$ & $\begin{array}{c}-0.005 \\
(0.002)\end{array}$ & $\begin{array}{c}-0.008 \\
(0.004)\end{array}$ \\
\hline Husband unemployed & $\begin{array}{c}0.084 \\
(0.094)\end{array}$ & $\begin{array}{c}-0.196 \\
(0.038)\end{array}$ & $\begin{array}{c}0.121 \\
(0.380)\end{array}$ & $\begin{array}{c}0.166 \\
(0.308)\end{array}$ & $\begin{array}{c}0.399 \\
(0.376)\end{array}$ \\
\hline Wife unemployed & $\begin{array}{c}0.012 \\
(0.099)\end{array}$ & $\begin{array}{c}-0.195 \\
(0.044)\end{array}$ & $\begin{array}{c}-1.089 \\
(0.600)\end{array}$ & $\begin{array}{c}0.136 \\
(0.311)\end{array}$ & $\begin{array}{c}0.742 \\
(0.366)\end{array}$ \\
\hline Husband not in the labor force & $\begin{array}{c}0.250 \\
(0.098) \\
\end{array}$ & $\begin{array}{r}-0.190 \\
(0.056) \\
\end{array}$ & $\begin{array}{c}0.603 \\
(0.366) \\
\end{array}$ & $\begin{array}{c}0.894 \\
(0.279) \\
\end{array}$ & $\begin{array}{r}-0.586 \\
(0.720) \\
\end{array}$ \\
\hline
\end{tabular}




\begin{tabular}{|c|c|c|c|c|c|}
\hline & \multicolumn{2}{|c|}{ Table 2 (col. B) } & \multicolumn{3}{|c|}{ Table 3a (Col. B) } \\
\hline & $\begin{array}{l}\text { Probability } \\
\text { of Migration }\end{array}$ & $\begin{array}{l}\text { Selection } \\
\text { Equation }\end{array}$ & Small & Med & Large \\
\hline Wife not in the labor force & $\begin{array}{c}0.035 \\
(0.047)\end{array}$ & $\begin{array}{l}-0.052 \\
(0.020)\end{array}$ & $\begin{array}{c}0.126 \\
(0.186)\end{array}$ & $\begin{array}{c}0.135 \\
(0.156)\end{array}$ & $\begin{array}{l}-0.258 \\
(0.228)\end{array}$ \\
\hline Either of spouses non-white & $\begin{array}{l}-0.125 \\
(0.050)\end{array}$ & $\begin{array}{l}-0.069 \\
(0.024)\end{array}$ & $\begin{array}{l}-0.401 \\
(0.206)\end{array}$ & $\begin{array}{l}-0.324 \\
(0.162)\end{array}$ & $\begin{array}{c}0.199 \\
(0.229)\end{array}$ \\
\hline Total family income & $\begin{array}{c}8.0 \mathrm{E}-08 \\
(5.9 \mathrm{E}-07)\end{array}$ & & $\begin{array}{c}3.9 \mathrm{E}-06 \\
(4.2 \mathrm{E}-06)\end{array}$ & $\begin{array}{c}1.0 \mathrm{E}-06 \\
(1.3 \mathrm{E}-06)\end{array}$ & $\begin{array}{c}1.2 \mathrm{E}-06 \\
(1.7 \mathrm{E}-06)\end{array}$ \\
\hline Disabled & & $\begin{array}{l}-0.020 \\
(0.027)\end{array}$ & & & \\
\hline Constant & $\begin{array}{l}-1.704 \\
(0.090) \\
\end{array}$ & $\begin{array}{c}0.732 \\
(0.028)\end{array}$ & $\begin{array}{c}-3.002 \\
(0.347)\end{array}$ & $\begin{array}{c}-3.954 \\
(0.295)\end{array}$ & $\begin{array}{l}-5.181 \\
(0.432)\end{array}$ \\
\hline Rho & \multicolumn{2}{|c|}{$\begin{array}{c}0.533 \\
(0.376)\end{array}$} & & & \\
\hline $\begin{array}{l}\text { Censored Observations } \\
\text { Uncensored Observations } \\
\text { Wald chi2(dof) }\end{array}$ & $\begin{array}{r}36 \\
219 \\
491.4\end{array}$ & & \multicolumn{3}{|c|}{$\begin{array}{c}21955 \\
922.8(75)\end{array}$} \\
\hline
\end{tabular}

The coefficients are presented with standard errors in parentheses. Standard errors are adjusted for clustering on household identifier. Bold coefficients are significant at the $95 \%$ confidence level or higher. 


\section{Appendix E - Urban/Non-Urban Occupations}

\begin{tabular}{|c|c|c|}
\hline URBAN OCCUPATIONS & \% Living in large MSAs & $\%$ with college degree \\
\hline Actuaries & 0.64 & 0.88 \\
\hline Aeronautical and astronautical engineers & 0.64 & 0.75 \\
\hline Stock and bond salesmen & 0.62 & 0.63 \\
\hline Podiatrists & 0.61 & 0.99 \\
\hline Economists & 0.59 & 0.77 \\
\hline Taxicab drivers and chauffeurs & 0.59 & 0.10 \\
\hline Mathematicians & 0.58 & 0.76 \\
\hline Computer systems analysts & 0.57 & 0.68 \\
\hline Office managers, nec & 0.56 & 0.65 \\
\hline Physicists and astronomers & 0.55 & 0.86 \\
\hline Sociologists & 0.55 & 0.80 \\
\hline Lawyers & 0.55 & 1.00 \\
\hline Architects & 0.55 & 0.82 \\
\hline Parking attendants & 0.54 & 0.04 \\
\hline Operations researchers and analysts & 0.53 & 0.53 \\
\hline Sales engineers & 0.52 & 0.62 \\
\hline Computer programmers & 0.52 & 0.56 \\
\hline Statisticians & 0.52 & 0.70 \\
\hline Life and physical scientists, nec & 0.50 & 0.96 \\
\hline Electrical and electronic engineers & 0.50 & 0.69 \\
\hline Accountants & 0.49 & 0.64 \\
\hline Civil engineers & 0.49 & 0.74 \\
\hline Writers, artists and entertainers & 0.48 & 0.46 \\
\hline Physicians, medical and osteopathic & 0.48 & 0.99 \\
\hline Psychologists & 0.48 & 0.93 \\
\hline Chemists & 0.48 & 0.82 \\
\hline Financial Officers & 0.47 & 0.50 \\
\hline Engineers, nec & 0.47 & 0.69 \\
\hline Sales managers/department heads, retail trade & 0.47 & 0.50 \\
\hline Buyers, wholesale and retail trade & 0.46 & 0.28 \\
\hline Salesmen and sales clerks, nec & 0.46 & 0.31 \\
\hline Managers and administrators, nec & 0.46 & 0.39 \\
\hline Chemical engineers & 0.46 & 0.84 \\
\hline Real estate agents and brokers & 0.45 & 0.37 \\
\hline Biological scientists & 0.45 & 0.89 \\
\hline Managers and superintendents, building & 0.45 & 0.33 \\
\hline Dentists & 0.44 & 0.99 \\
\hline Urban and regional planners & 0.44 & 0.77 \\
\hline Health practitioners, nec & 0.43 & 0.81 \\
\hline
\end{tabular}

Con't 


\section{URBAN OCCUPATIONS (Con't)}

Personnel and labor relations workers

Advertising agents and salesmen

Archivists and curators

Mechanical engineers

Geologists

Purchasing agents and buyers, nec

Computer specialists, nec

Optometrists

Demonstrators

\section{NON-URBAN OCCUPATIONS}

Clerical and kindred workers

Clinical laboratory technologists, technicians

Officials of lodges, societies, and unions

Therapists

Health administrators

Hucksters and peddlers

Industrial engineers

Technicians, not health/engineering/science

Protective service workers

Salesmen

Librarians

Private household workers

Social workers

Public administrators, nec

Insurance agents, brokers, and underwriters

Registered nurses

Petroleum engineers

Inspectors, not construction/pubadmin

Engineering and science technicians

Restaurant, cafeteria, and bar managers

Health technologists/technicians, nec

Religious workers, nec

Conductors and motormen, urban rail transit

School administrators, elem and sec

Construction inspectors, pub admin

Sales managers, except retail trade

Judges

Dental hygienists

Pharmacists

Social scientists, nec
\% Living in large MSAs \% with college degree

0.43

0.39

0.43

0.40

0.42

0.70

0.42

0.60

0.41

0.84

0.41

0.29

0.41

0.14

0.41

0.99

0.40

0.12

\% Living in large MSAs \% with college degree

0.39

0.11

0.39

0.43

0.39

0.47

0.39

0.67

0.39

0.47

0.39

0.24

0.39

0.53

0.39

0.29

0.39

0.15

0.39

0.19

0.39

0.62

0.38

0.04

0.38

0.64

0.38

0.44

0.38

0.38

0.38

0.45

0.37

0.77

0.37

0.26

0.37

0.21

0.37

0.09

0.37

0.16

0.37

0.56

0.37

0.14

0.37

0.69

0.36

0.17

0.36

0.23

0.36

0.68

0.36

0.33

0.35

0.88

0.35

0.55

Con't 


\section{NON-URBAN OCCUPATIONS}

Metallurgical and materials engineers

Bus drivers

Teachers, college and university

Air traffic controllers, flight engineers

Atmospheric and space scientists

Teachers, except college and university

Postmasters and mail superintendents

Railroad brakemen

Craftsmen and kindred workers

Service workers

Dietitians

Railroad conductors, Airplane pilots

Recreation workers

Newsboys

Radiology technologists and technicians

Laborers, except farm

Deliverymen and routemen

Health record technologists and technicians

Health service workers

Truck drivers

Operatives, except transport

Veterinarians

Clergymen

Officers, pilots, and pursers; ship

Agricultural scientists

Funeral directors, embalmers

Fork lift and tow motor operatives, motormen

Boatmen and canalmen

No Occupation

Railroad switchmen

Buyers and shippers, farm products

Auctioneers

Mining engineers

Foresters and conservationists

Laborers, natural resources

Service workers, except private household
\% Living in large MSAs \% with college degree

$0.34 \quad 0.68$

$0.34 \quad 0.05$

$0.34 \quad 0.88$

$0.34 \quad 0.20$

$0.33 \quad 0.46$

$0.33 \quad 0.79$

$0.33 \quad 0.18$

$0.33 \quad 0.06$

$0.33 \quad 0.05$

$0.32 \quad 0.05$

$0.32 \quad 0.52$

$0.32 \quad 0.53$

$0.32 \quad 0.28$

$0.31 \quad 0.08$

$0.31 \quad 0.13$

$0.31 \quad 0.04$

$0.31 \quad 0.07$

$0.30 \quad 0.12$

$\begin{array}{ll}0.30 & 0.07\end{array}$

$0.28 \quad 0.03$

$0.28 \quad 0.04$

$0.27 \quad 0.98$

$0.26 \quad 0.74$

$0.26 \quad 0.16$

$0.25 \quad 0.63$

$0.23 \quad 0.29$

$0.23 \quad 0.02$

$0.22 \quad 0.07$

$0.20 \quad 0.21$

$0.19 \quad 0.04$

$0.17 \quad 0.14$

$0.15 \quad 0.20$

$0.10 \quad 0.62$

$0.09 \quad 0.66$

$0.09 \quad 0.05$

$0.08 \quad 0.09$

Figures are calculated from the 1990 public use files of the Census (Ruggles and Sobeck, 1997). Urban occupations are defined as those for which at least $40 \%$ of individuals in the occupation live in MSAs of at least 2million. 